\author{
Krzysztof Lewandowski \\ Dr inż. \\ Politechnika Wrocławska \\ Krzysztof.lewandowski@pwr.edu.pl
}

\title{
Draisine railway of the Dolina Bobru
}

\begin{abstract}
The basis of this article is the proposal to use bicycle rail trolleys as preventive measures before draisining the Dolina Bobru railway line. This tourist attraction can be promotion for the poviat of the Lwówek Śląski. This can help to reconstruction of the regular rail connection between Legnica-Złotoryja-Lwówek Śląski-Jelenia Góra..
\end{abstract}

Keywords: Rail line; Protection; Draisine haulages

\section{Draisine}

The term "draisine" is understood as an auxiliary railway vehicle with manual or combustion drive. The first such a construction of a road vehicle repelled with legs (welocyped) was introduced in 1817 by Karl Drais, whose name gave the name of this vehicle. In 1839, the first classic railcar was used on the Beaune-Dijon railway line, $37 \mathrm{~km}$, in France. in 1855 Pierre Michaux introduced the railway bike. In 1903, a version of a draisine with an internal combustion engine appeared [19].

\section{Selected draisine railways in Poland}

Currently, in Poland, draisines are offered on selected railway lines:

Draisine railway in Łapina near Kolbud in the Pomeranian Province. The first trip was made on 17.08.1998 on the Stegna - Sztutowo - Stegna route. Currently, the Draisin Railway operates on the 16th-kilometer route of the following route: Niestępowo - Stara Piła - Łapino Papiernia - Kolbudy Jaz Wodny and on the touristic route of draisine on Westerplatte in Gdańsk. 29.05.2003 The Draisine Railway signed agreements with PKP PLK ZLK on the

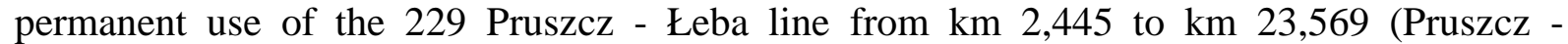
Niestępowo). Draisine Railway has a rolling stock consisting of 4 railway bicycles and 4 draisins12-seat type pump (4 people waving) [12].

Mosińska Draisine Railway in Mosina in the Wielkopolski National Park in the Wielkopolska Province. It was established in 2013 on the initiative of Maria Stachowiak. Mosińska Draisine Railway runs on the route Puszczykówko-Mosina Pożegowo - Osowa Góra on the railway line 361, Puszczykówko - Osowa Góra. Mosina commune expressed a desire to take over this railway line from PKP PLK. Mosińska Draisine Railway has three specially designed rail draisins (Fig.1) [16]. 


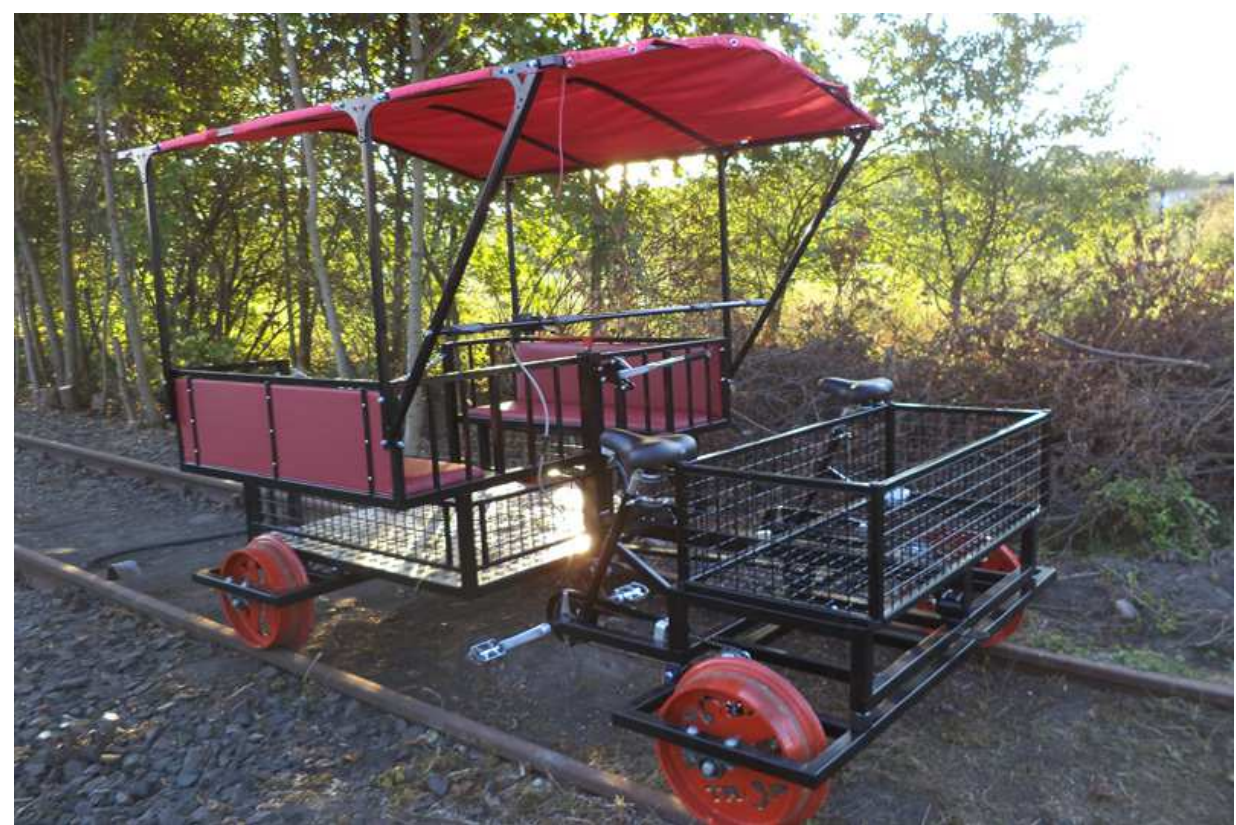

1. Mosińska Draisine Railway, Author: Maria Stachowiak - Krzyżaniak, 2013. [24]

Bieszczadzkie Bike Draisines in the Podkarpackie Voivodeship. Founded on the initiative of Janusz Demkowicz and the support of the Olszanica commune, which took over from PLK the closed line 108 from Zagórze to Krościenka, $46 \mathrm{~km}$ long. Its value was estimated at PLN 3 million along with infrastructure, stations, duty stations, and viaducts, and then it was transferred to a Bieszczady entrepreneur. Currently, the main base is the station in Uherce Mineralne. There are 50 four-seat (driven by 2 cyclists) railway bikes (fig. 2) [3].

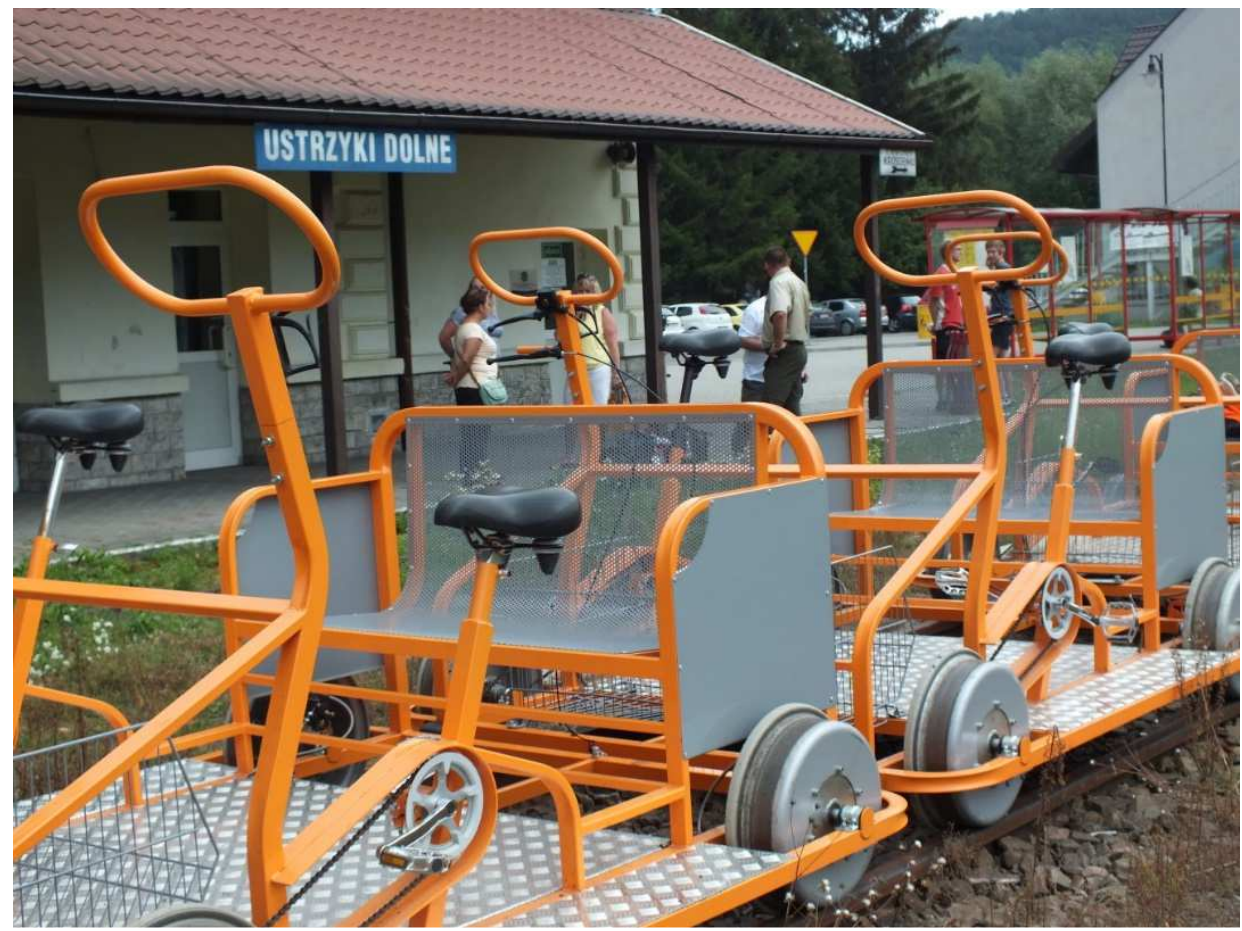

2. Bicycle draisine in Bieszczady in Ustrzyki Dolne, Author: Bajda Paulina, Gazeta Bieszczadzka, August 2015. [2] 
In 2015 Bieszczadzkie Bike Draisines were considered the best tourist product of the Podkarpackie Voivodeship and Poland 2015 [18].

Local Draisine Railway in Regulice in Małopolskie Voivodeship. The initiative actions were taken in 2015 by railway fans Grzegorz Pater and Michał Ściana from the Friends of Regulice and Nieporaz Association. On July 1, 2017, the first crossing was made on a five-kilometer section of the 103 Trzebinia - Wadowice railway line between Regulice Górne and Alwernia (the former marina of Nieporaz(Oblaszki) - $8.660 \mathrm{~km}$ and the Alwernia Spalona stop - 14,260 km). Local Draisne Railway has three four-passenger railway bicycles of the type used in the Bieszczady Mountains [15].

Grodziska Draisine Railway in the Wielkopolska Province. Grodzisko Kolej Drezynowa has been operating since 2005 on a $30 \mathrm{~km}$ section between Grodzisk Wlkp. Kościan on the 376 railway line, leased from PKP PLK. Originally, the line connected the Kościan - Opalenica station. Currently, Grodzisk Draisine Railway has in its stock 4 handoperated draisines of the pump type, and one car Fiat 126p adapted for running on the $1435 \mathrm{~mm}$ track and 3 towing the railway platform for passengers. In addition, motor vehicles are in stock: 2 WM5 draisines, 2 409Da-541 locomotives, 1 Ls40-4570 locomotive, and 3 different standard gauge rail cars and others. The home station is Ujazd Wlkp. Grodzisk Draisine Railway since 2017 is the Public Benefit Organization KRS: 0000254917 [10].

Krzywińska Draisine Railway operating since 2005 on the other side of the 271 Wrocław Poznań railway line at the Bieżyń station in the Wielkopolska Province. Krzywińska Draisine Railway operates on a $40 \mathrm{~km}$ section between Gostyń and Kościan on the 366 Miejska Górka - Kościan railway with the support of the Krzywiń commune. The rolling stock of Krzywińska Kolej Jezyniowa consists of 2 manual draisines, a pump type and 2 motor draisines (SAM and WM5 type). The mother station is in Bieżyna [14].

Sowiogórskie Bractwo Kolejowe (SBK) in the Lower Silesian Province. SBK has been operating since 2003 on the approximately $16 \mathrm{~km}$ section between Świdnica Kraszowice and Jugowice on the 285 Wrocław-Jedlina Zdrój railway line. The main idea of the Sowieogórski Brotherhood of the Railway is to block PKP's intentions for the physical liquidation of the "Weistritzthalbahn" line connecting Świdnica Kraszowice and Jedlina Zdrój by launching a draisine railway so that the trains could return to the mountain section of line 285 . The main station of SBK is Jugowice. The SBK rolling stock consists of 2 hand-operated draisines of the pump type and 3 of the SAM motor draisines. SBK cyclically organizes competitions in tuning [23].

Karkonowskie Manual Draisines (KDR) in the Lower Silesian Voivodship. KDR has been operating since 2005. on the initiative of Rafał Gersten, within the Karpacz station on the 340 Mysłakowice - Karpacz railway line. The main station of the Karkonoskie Hand Drezda is Karpacz. The rolling stock is one hand-operated type of pump. In 2006, the Karkonoskie Hand Dressers were considered the Most Interesting Tourist Product of Karpacz [7].

\section{Draisining with the form of protection of railway lines}

The forms of the initiative of establishing a draisine railway indicate the desire to protect railway lines against physical liquidation. Very often it was an initiative of natural persons who found understanding and recognition of local self-government. Municipal selfgovernment being the basis of local self-government in Poland have broad obligations under the Local Government Act of the commune enshrined in Art. 7. 1) [26].Self-governments are institutions that have contact with residents planning, among others local collective transport within the so-called collective needs of the community. The commune as the basic unit of territorial self-government can act as a legal representative of a higher local government unit (poviat or marshal's office) in front of the current owner of the railway line. The commune 
cannot, due to a number of mandatory statutory tasks, operate a regular railway connection, but it can, and should, operate to protect the railway line. The Marshal's office, due to the statutory superiority over the commune, is obliged to have communication plans for the area of the entire voivodship. This is due to the fact that the railway line passes through several municipalities and even province. Thus, the commune may only be a legal supervisor on behalf of the marshal's office over the railway line. The commune and the district may, due to the size of the budget, participate in the protection of railway lines through dreamy - like the commune of Ustrzyki Dolne. This indicates the application of the Public Private Partnership (PPP) principle. The presented examples indicate a favorable position of communes aimed at protecting railway lines in terms of potential passenger traffic reconstruction. Very good examples are the activities of the municipalities of Mosina, Olszanica, Regulice, Grodzisk Wlkp., Krzywiń, and Walim and Karpacz. The case of the Radków commune in the Lower Silesian Voivodship is interesting. In 2006, the Municipality of Radków responded to the request of a company concessionaire to extract melaphyre in the commune for mining conditions. In its position, the Commune of Radków ordered the reconstruction of the closed railway line Tłumaczów-Ścinawka Średnia and drastically limited the possibility of using road transport to export aggregate [4]. In 2010, the railbus of the Lower Silesian Railways crossed the reconstructed railway line [28].

The same applies to the railway line 285 on the section Świdnica Kraszowice-Jedlina Zdrój. Thanks to the involvement of SBK and local governments of Głuszyca, Jedlina Zdrój, Świdnica, Walimia, and Wałbrzych, on October 25, 2018, PKP PLK signed with Dolkom S.A. a contract for the revitalization of the railway line No. 285 on the section Świdnica Kraszowice - Jedlina-Zdrój for PLN 109995 million net with EU funding in the amount of PLN 94295 million. The expected end of work on this section of line 285 is November 2020 [21]There are also known cases of the negative attitude of local governments from Lower Silesia, which led to the physical liquidation of railway lines. A scandalous example is the self-government of the Kamienna Góra Municipal Commune. As a result of his decision, there was a physical liquidation of the 330 Kamienna Góra -Okrzeszyn railway line also called the Zadrna Valley Railway (German: Ziedertalbahn AG) or the sausage railway. At the station in Krzeszów, in 2017, road transport was carried out. Unfortunately, in January 2018, the physical liquidation of the railway line was started by dismantling the track [8]. Thus, the possibility of using the case of the Radków commune for handling the export of aggregate from the planned melaphyre quarry in Okrzeszyn was lost.

The second example is the railway line 334 Kamieniec Ząbkowicki-Złoty Stok. Still, in 2016, they were tramped at the station in Złoty Stok. The line was pulled down in 2017 [6]. A similar fate was met in 2014 by Ząbkowicka Powiat Railway. The tracks from Ząbkowice Śląskie to Kondratowa no. 320 and from Ciepłowodów to Henryków nr 335 were dismantled. At the Ząbkowice station, the Silesian Association of SEMAFOR Rail Fans performed draisine passages [5] [13].

Currently, the problem of liquidation of railway lines in Lower Silesia has affected one of the most beautiful lines No. 283 on the section Jelenia Góra - Rakowice Żwirownia. On April 23, 2018, the owner of the PKP PLK line introduced a speed of $0 \mathrm{~km} / \mathrm{h}$ on the section Jelenia Góra - Rakowice Żwirownia [17].

\section{Railway line 283 on the section Jelenia Góra - Zebrzydowa}

The 283 railway line was created by sections. As the first in 1905, section Zebrzydowa Lwówek Śląski was built. The next was in 1906 the section Jelenia Góra - Siedlęcin with an extension to Pilchowice. The Pilchowice -Lwówek Śląski episode was completed as a complete one for use in 1909 For many years, there were few cargoes holds and passenger stations on this line [11], see Figure 3. 


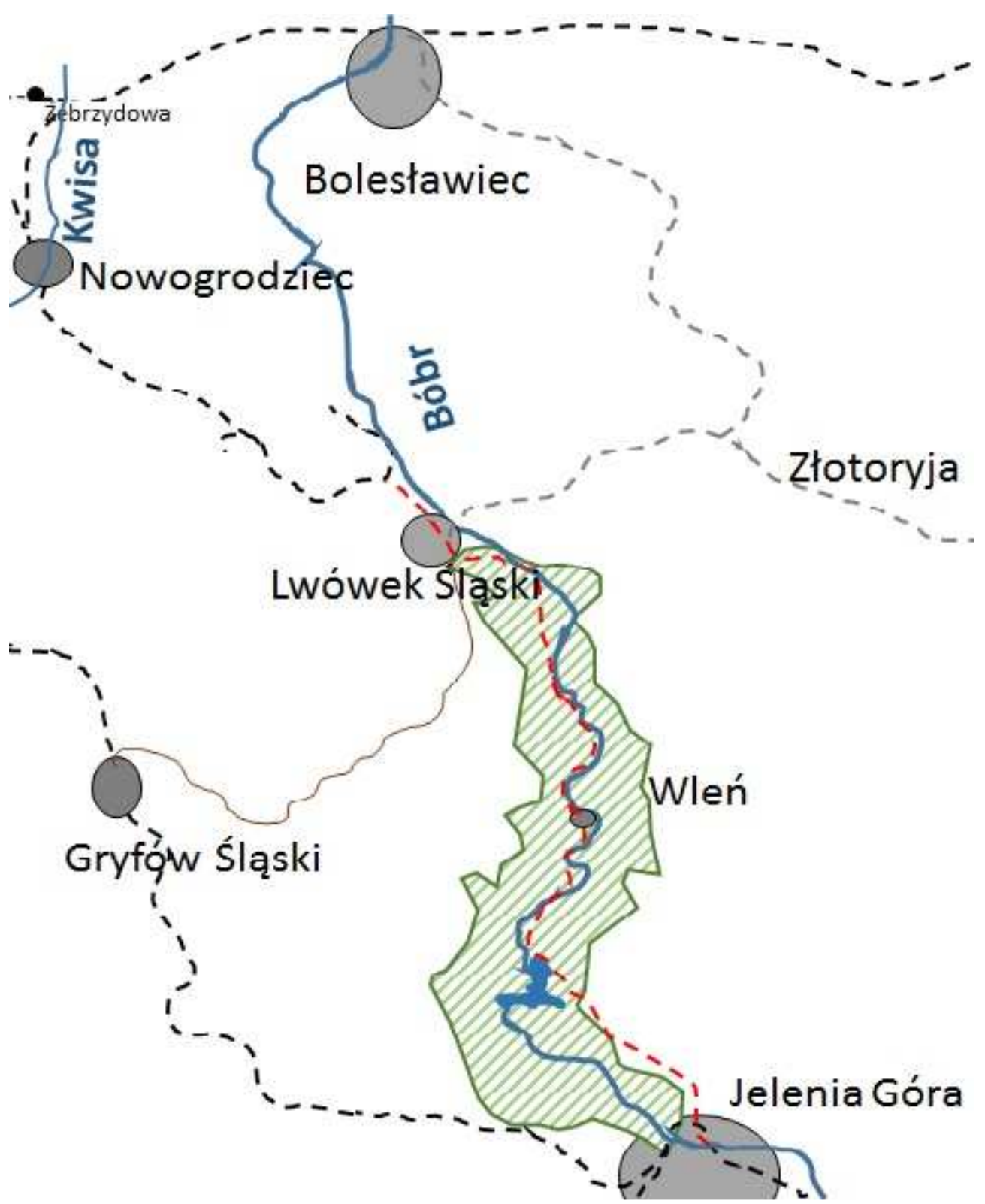

3. Schematic map of the location of the Bóbr river, the Dolina Bobru railway, the Dolina

Bobru Landscape Park and the E30, 274, 283 and 284 railway lines

Currently, after the economic changes on this section of the 283 line there are 3 active holds: Sidetrack "Surmin", Niwnice and Rakowice Żwirownia and 10 passenger stations. The surface on the 283 line is a classic track on wooden sleepers, K-type fastening, S49 rail. The speed of the ride depended on the section. From Zebrzydowa to Rakowic Żwirownia $40 \mathrm{~km} / \mathrm{h}$, from Rakowic Żwirownia to Jelenia Góra $10 \mathrm{~km} / \mathrm{h}$, sections $20 \mathrm{~km} / \mathrm{h}$. Line 283 departs from line E30 Wrocław-Dresden with an arched embankment just after crossing the Kwisa River in Zebrzydowo (Figures 4 and 5). In Ołdrzychów passes the Surmin siding (Figure 6). In the town of Nowogrodziec (Fig. 7) it crosses the Kwisa River (Fig. 8), then the siding in Niwice (Fig. 9) and Rakowice Wielkie goes by (Fig. 10). At the entrance to Lwówek Śląski passes the Brunów Palace (Figure 11) and the railway bridge on the Bóbr River on the line 284 Legnica Pobiedna connecting Lwówek Śląski and Jerzmanice Zdrój (Figure 12). Immediately after the Lwówek Śląski station, there is an overgrown passage of the 284 line to Gryfów Śląski (Figure 13), which is now a bicycle path (the course is marked in brown in Figure 3). On the 
section from Lwówek Śląski to the Pilchowice station, Nielestno railway line 283 runs very close to the Bóbr river.

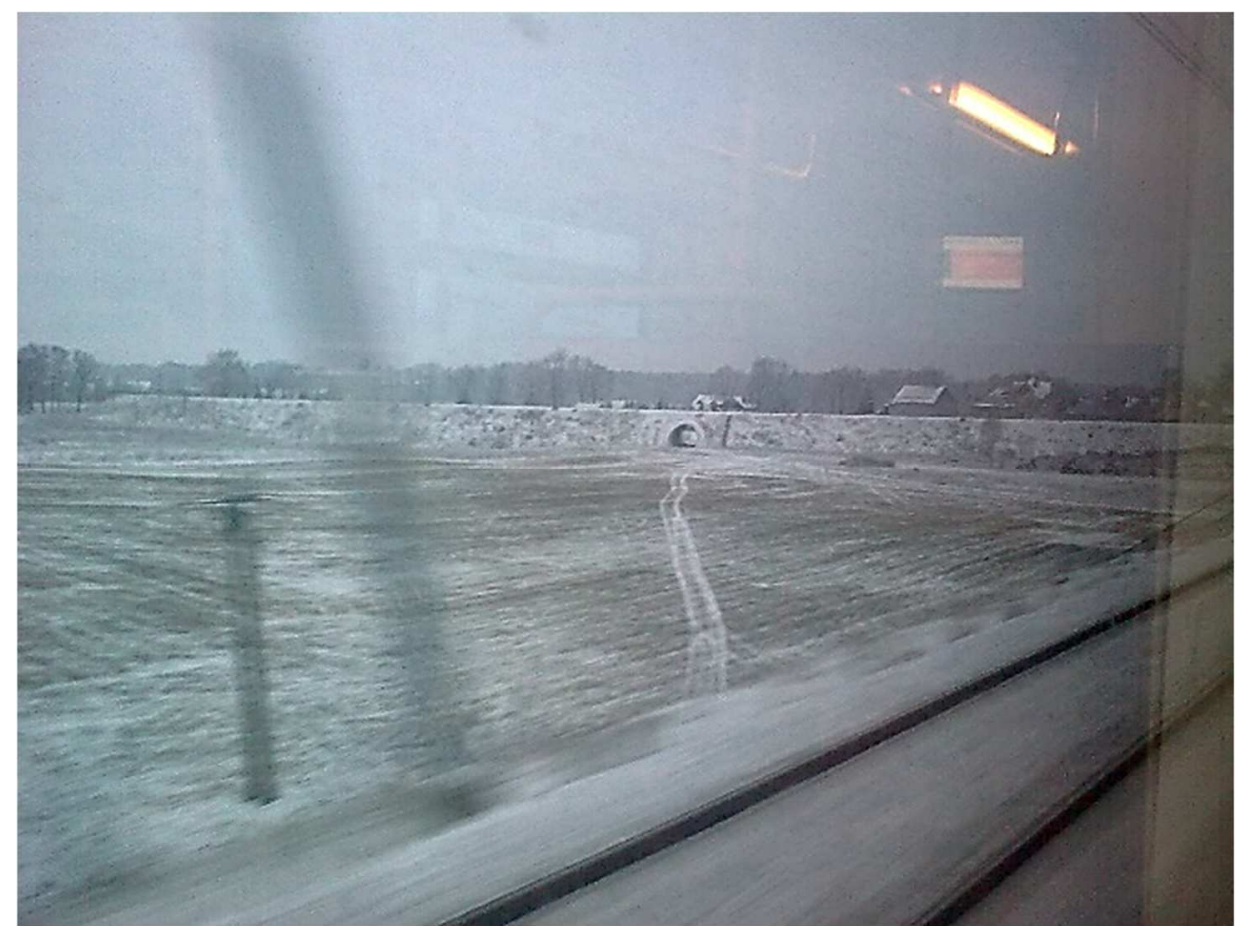

4. View of embankment line 283 above the viaduct on the Kwisa River near Zebrzydowa on the E30 line

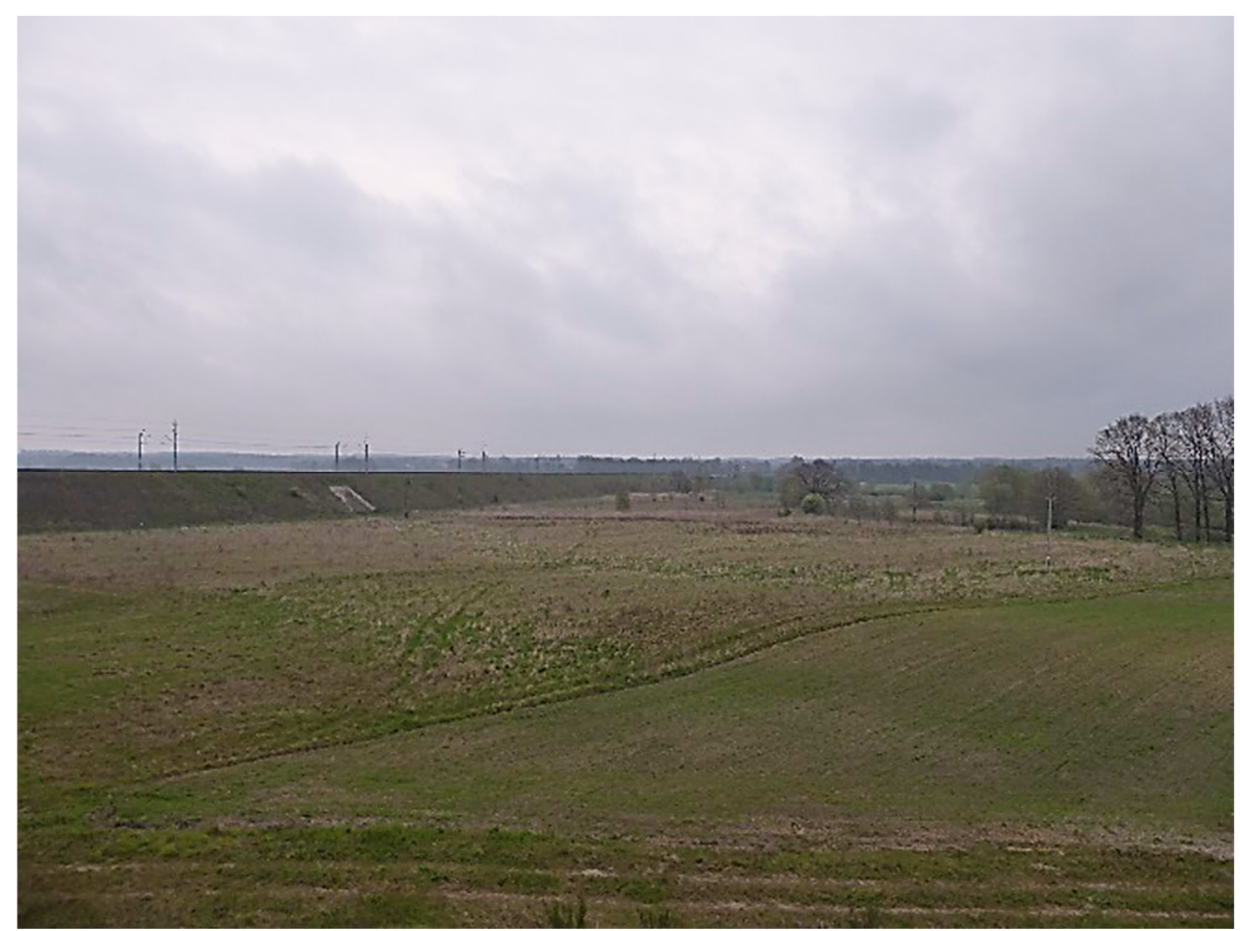

5. View of the embankment and viaduct over the Kwisa river, on the E30 railway line from line 283 near Zebrzydowa 


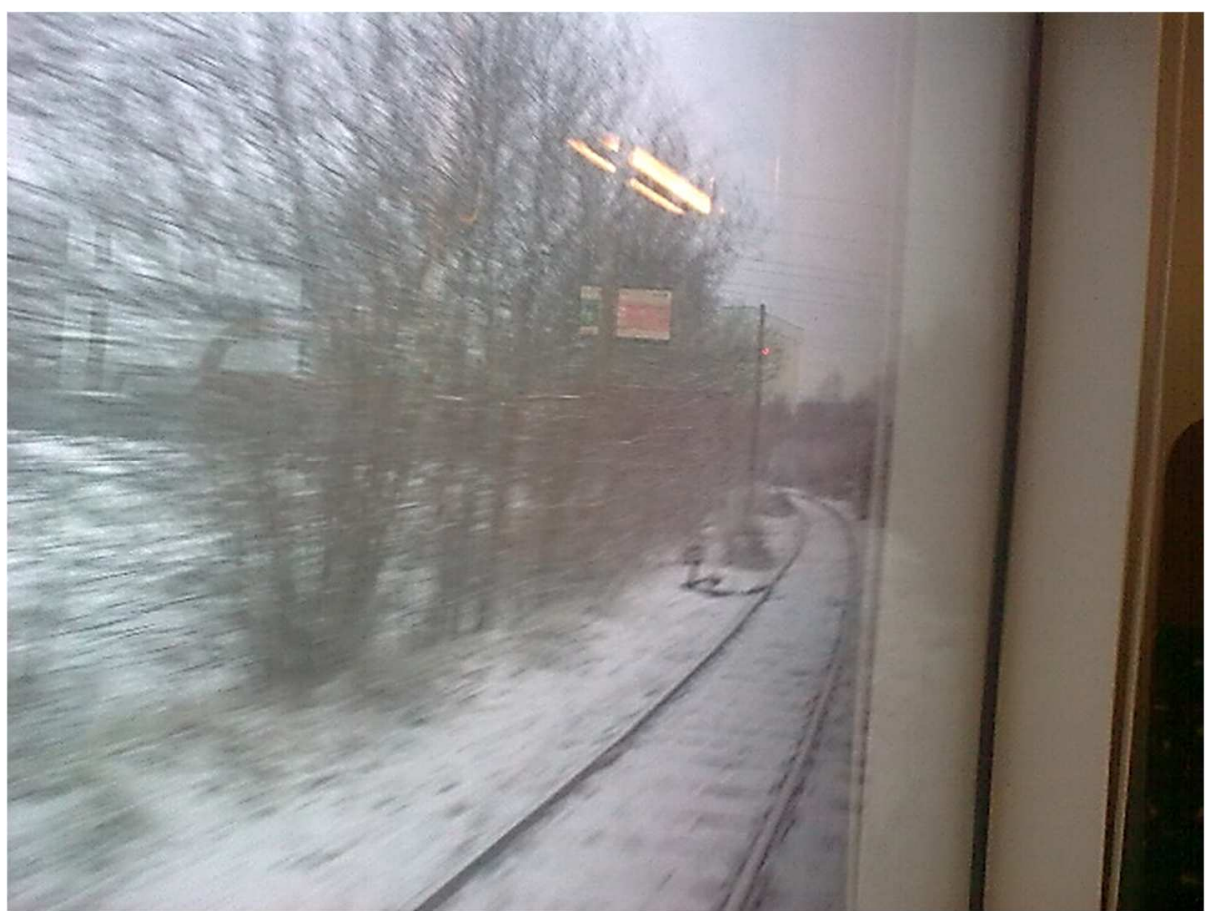

6. View of the departure of the siding to the Surmin-Kaolin Mineral Resources Mine S.A. in Ołdrzychów

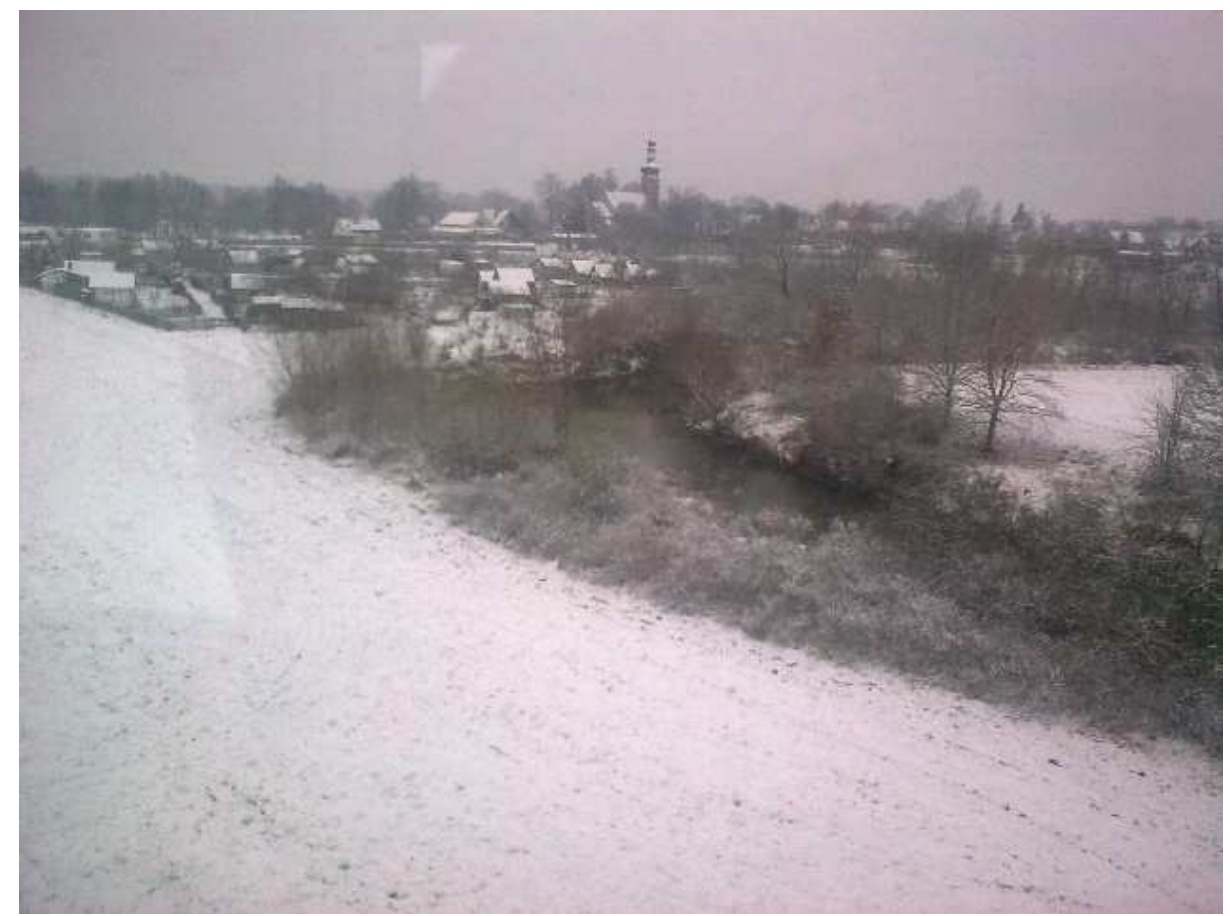

7. Nowogrodziec and Kwisa river in winter scenery 


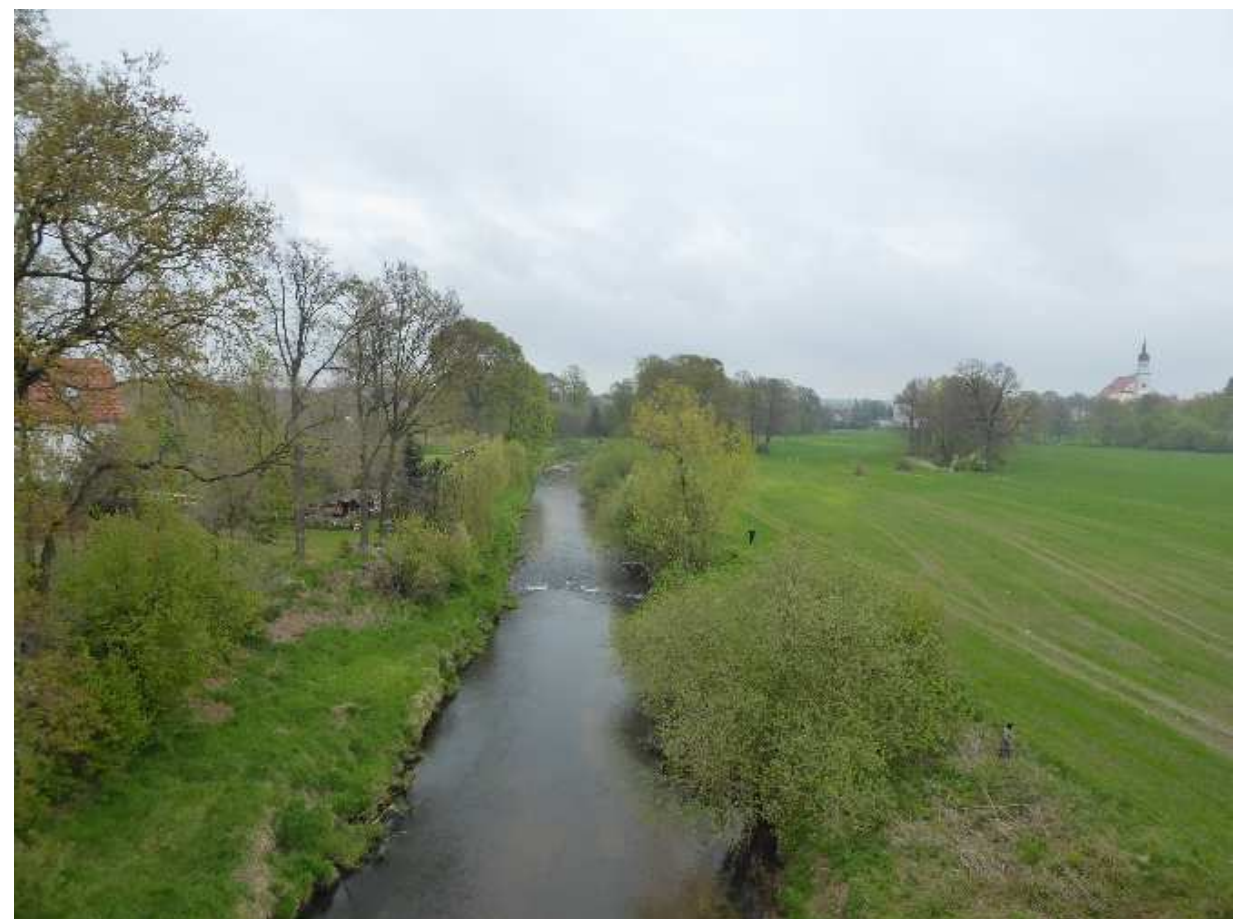

8. Kwisa river from line 283 towards Lubań

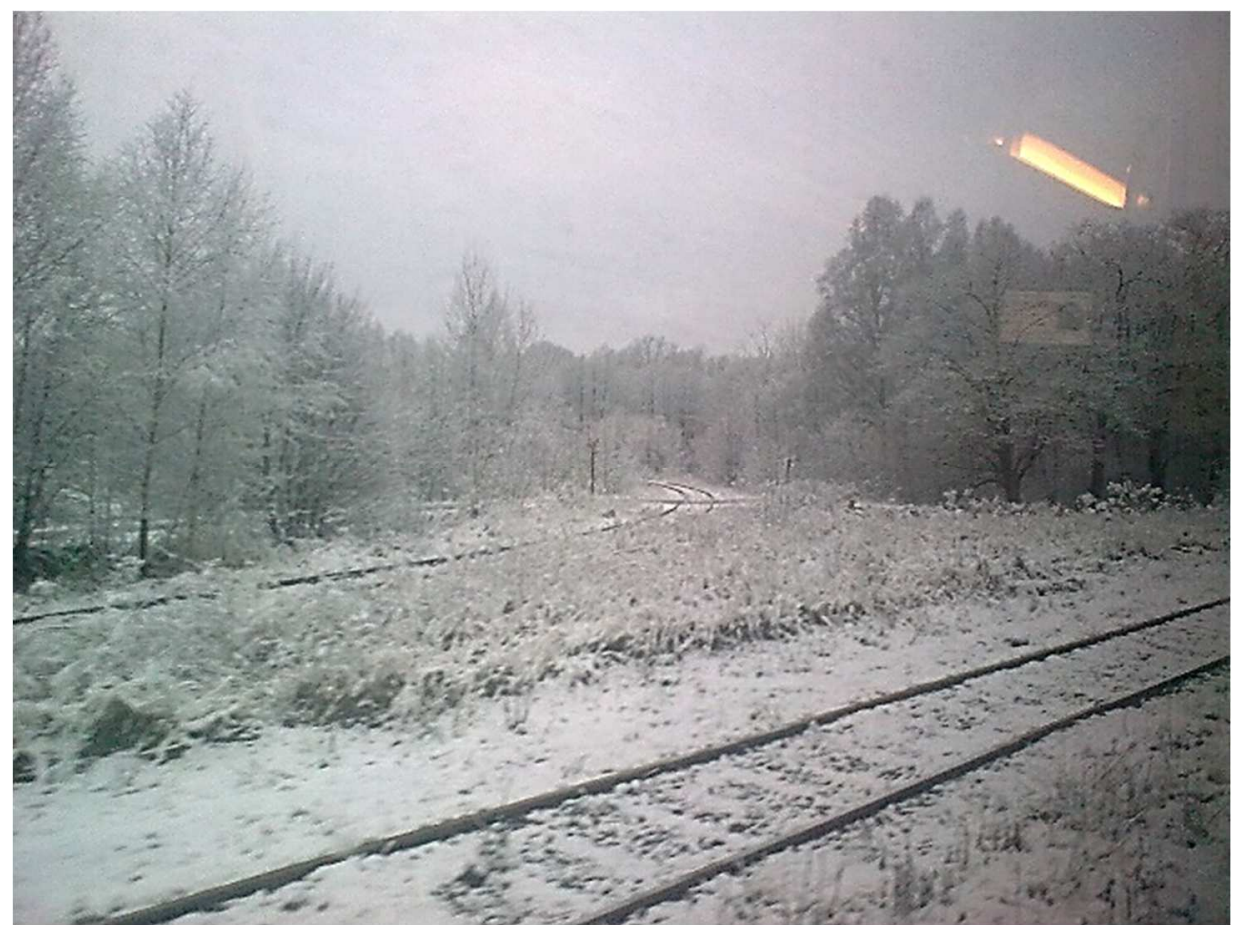

9. View of the departure of the siding to the plants of Nowy Ląd sp. O.o. Gypsum and Anhydrite Mine in Niwnice 


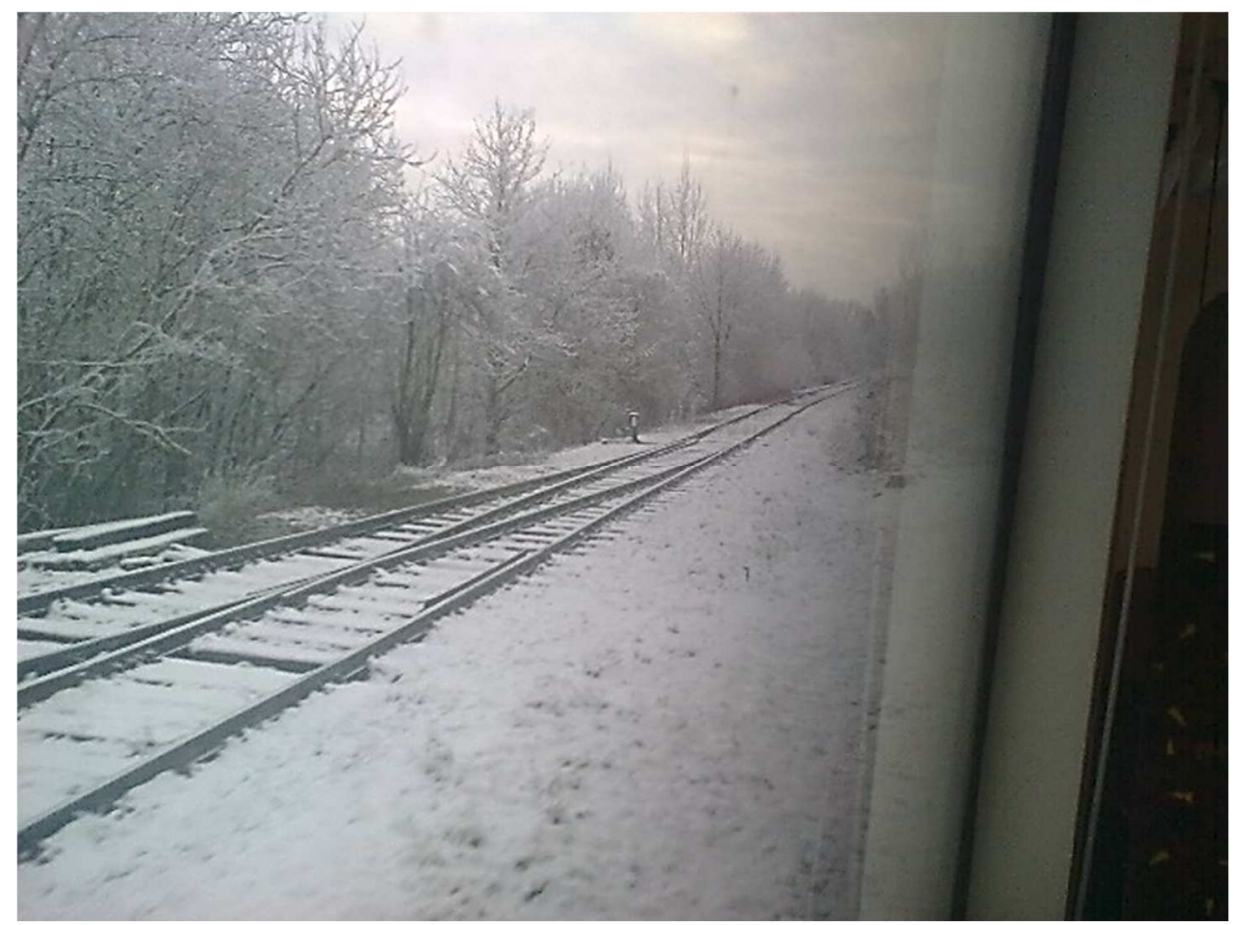

10. View of the departure of the siding to the plants of KSM Rakowice Grupa Górażdże in Rakowice Wielkie

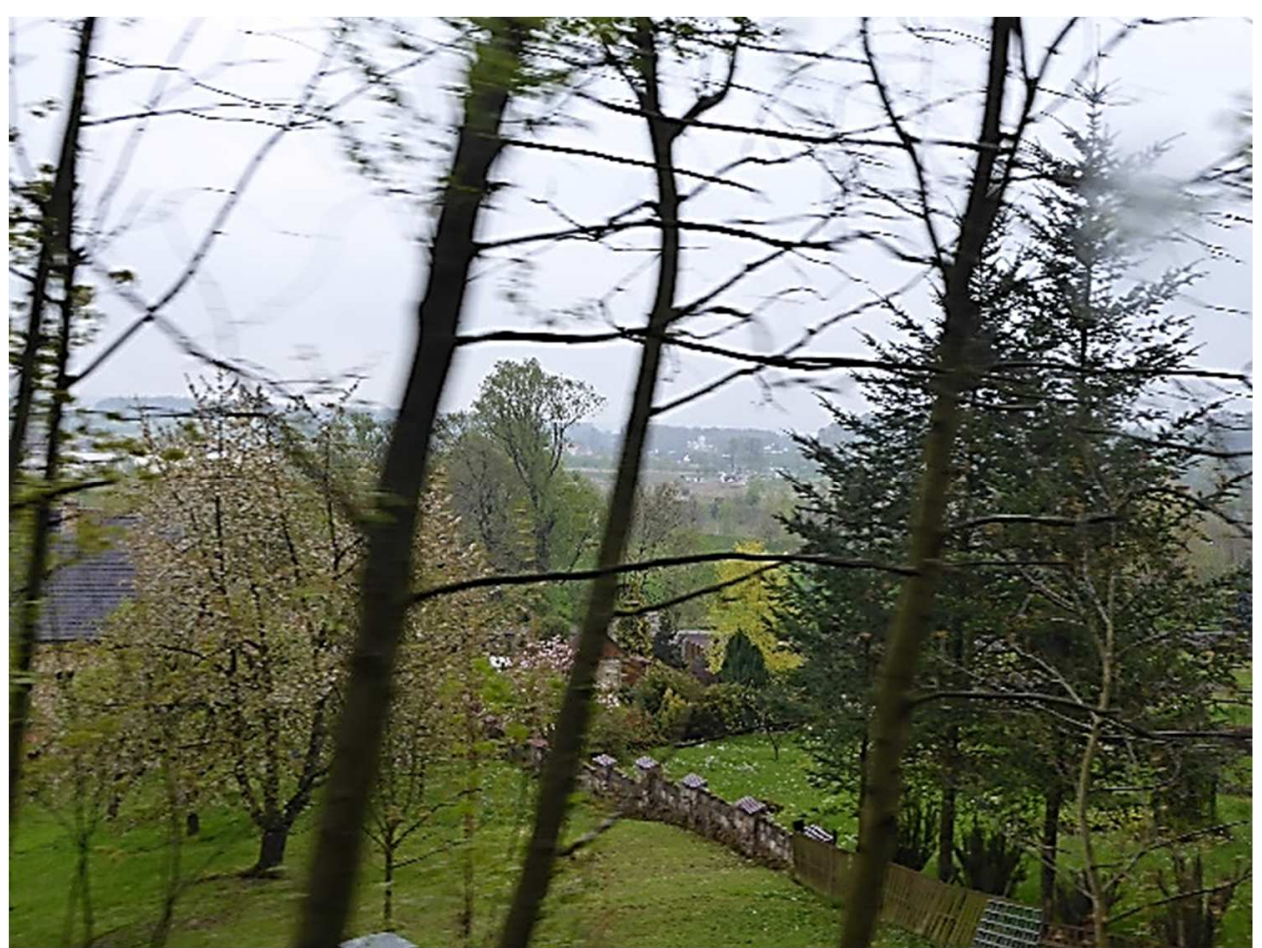

11. The white tower of the palace in Brunów visible between the trees at line 283 


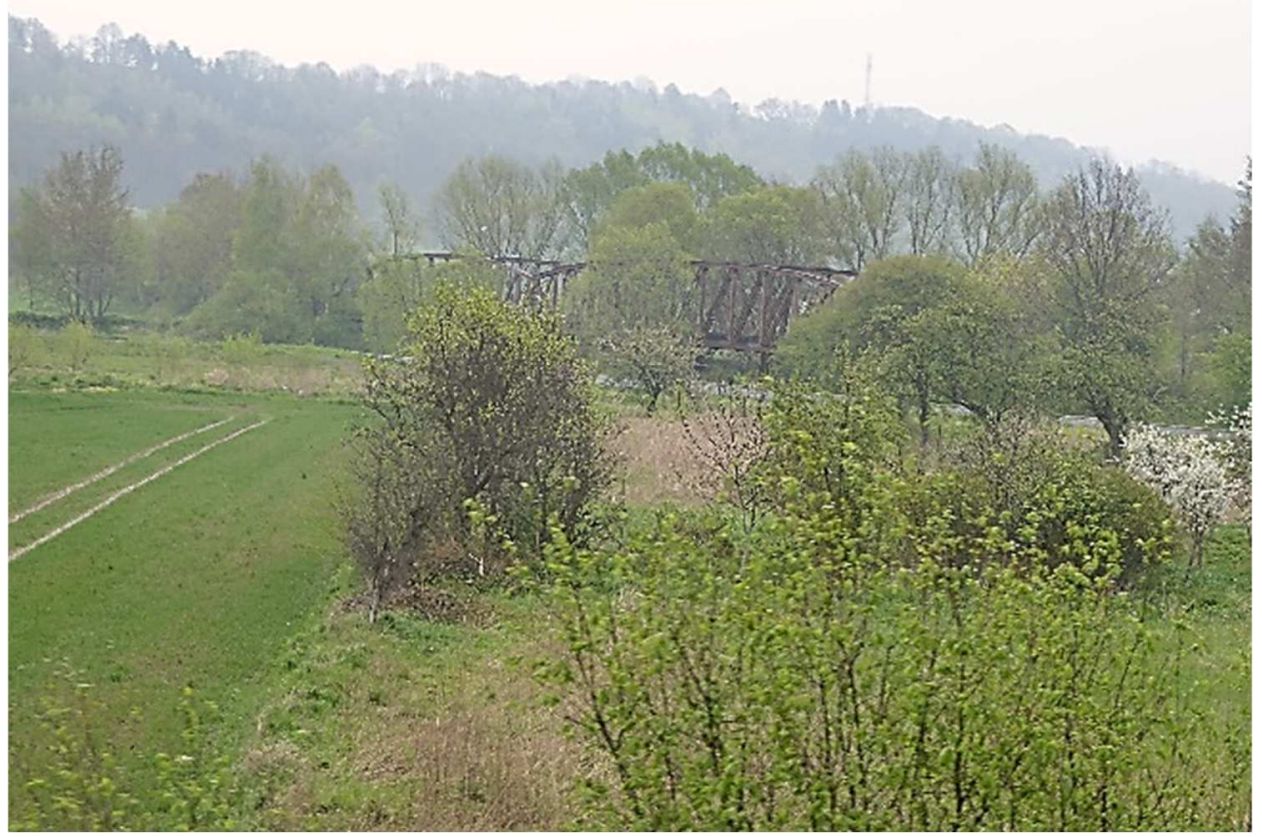

12. Railway bridge to Jerzmanice Zdrój on the Bóbr river

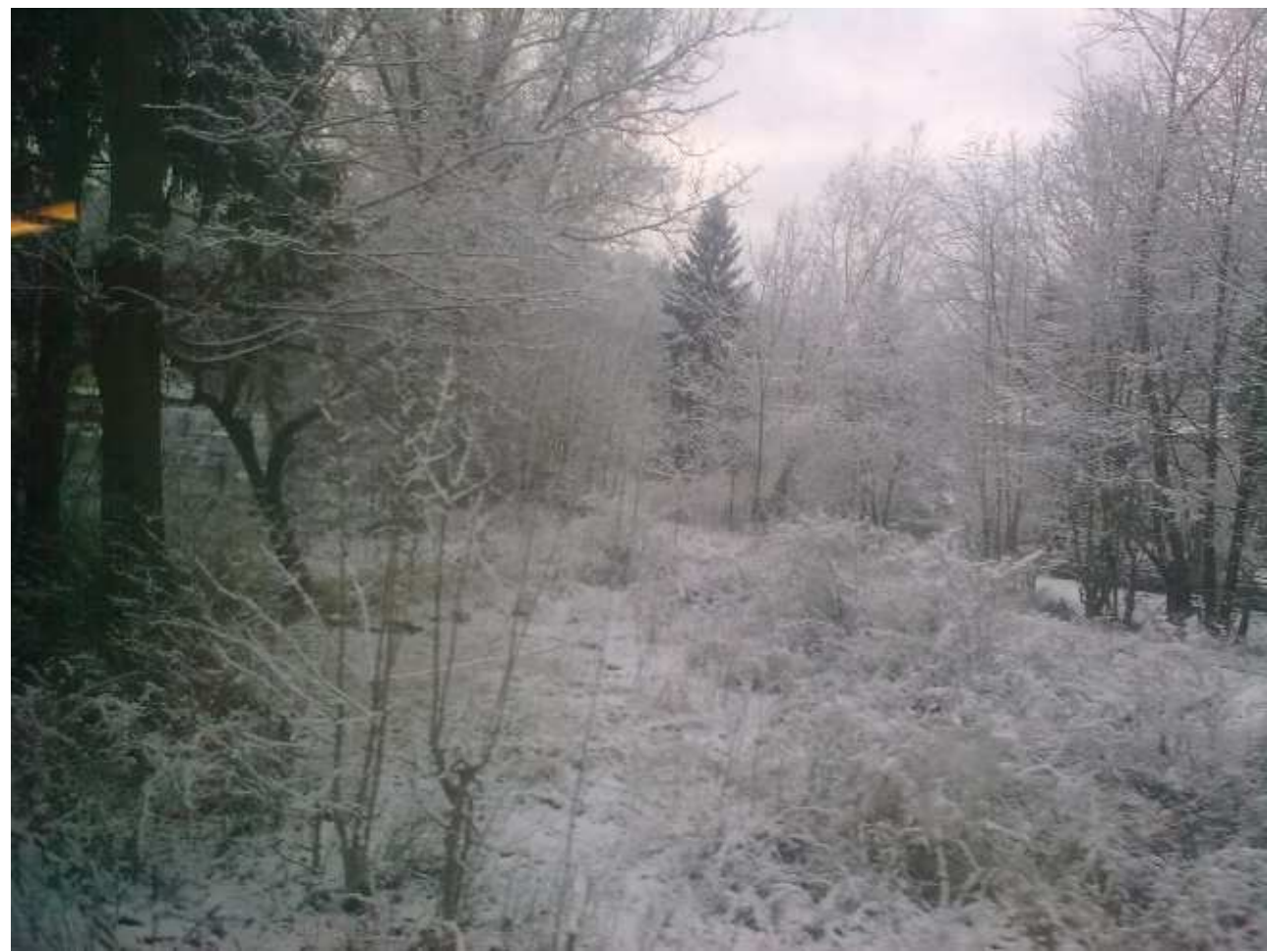

13. Overgrown and covered with snow departure of line 284 to Gryfów Śląski from Lwówek Śląski

The Bóbr river meanders in a very narrow valley, see fig. 14. When riding a line, you have the impression that you can touch the water in the Bóbr River (Fig.15). Behind the Wlen station (Figure 16), the line goes through a tunnel (Figure 17) and once again it crosses the river going to Pilchowice Nielestno (Figure 18). From this section to Pilchowice, the line goes 
up a steep climb. At the Pilchowice Zapora station, there is a view from the train to the Pilchowicka Dam with an inseparable cable hanging too low (Fig. 19). Then the line goes through the viaduct over the bay of Pilchowicki Lake next to the hills of Mały Grzbiet, Strzyżów 424 m.n. and Lime $507 \mathrm{~m}$ above sea level, (Fig. 20) through Siedlęcin to Jelenia Gora. Just before the station, the line goes under the viaduct on the 311 Jelenia Góra Jakuszyce line (Figure 21) and again crosses the Bóbr. After April 23, 2018, just after the Jelenia Góra station, the track surface of the 283 line was removed from the bridge over the Road Workers' Housing in Jelenia Góra across the bridge over the Bóbr River to the heating plant. The material was placed under the viaduct of the national road No. 3 (Aleja Jana Pawła II in Jelenia Góra) (Fig. 22). On the western exit head of the Jelenia Góra station on the 283 line, there is a stopping disc with the signal D1 "Stop" (Fig.23)).

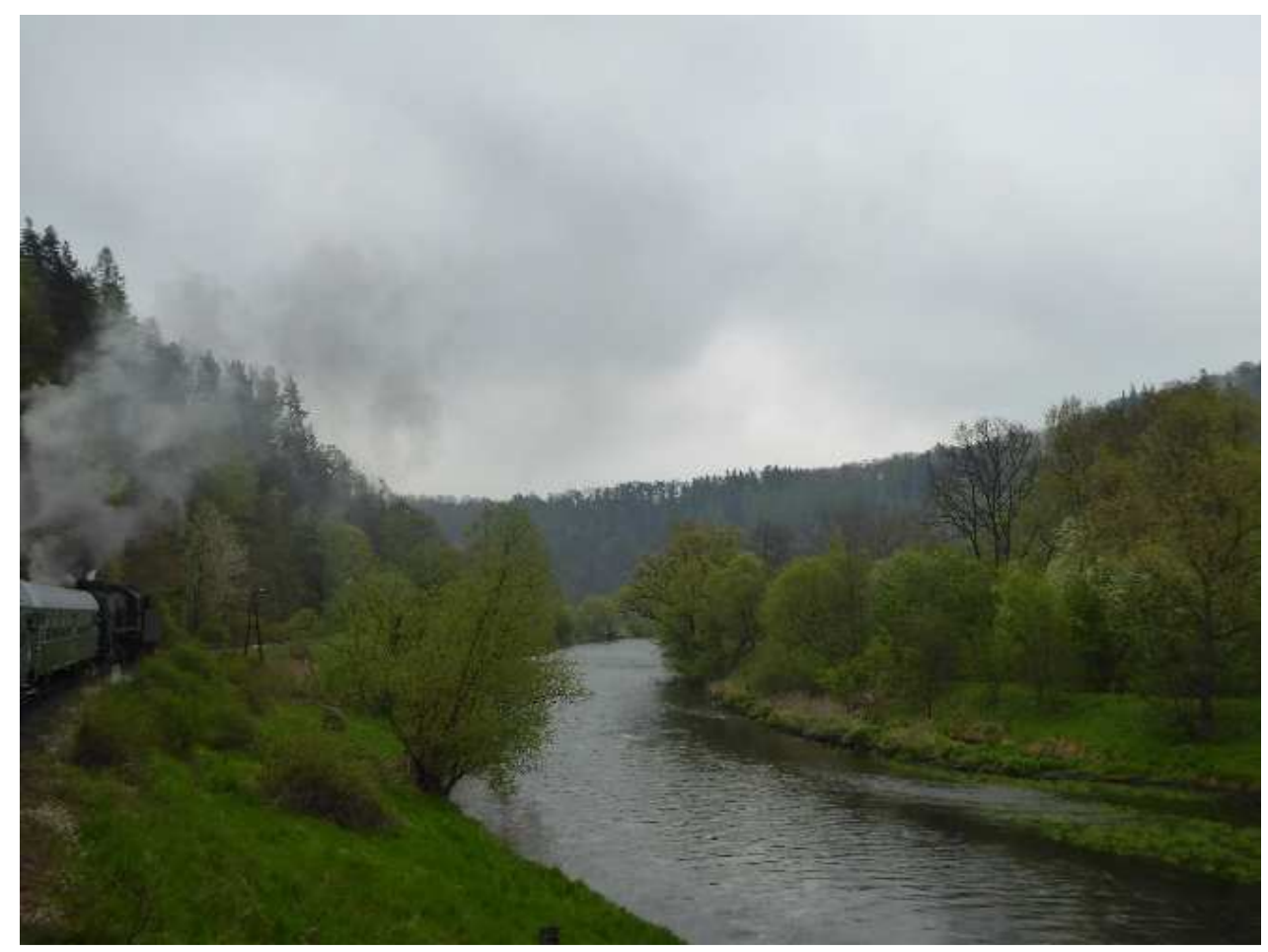

14. Train and river under a weeping rain sky 


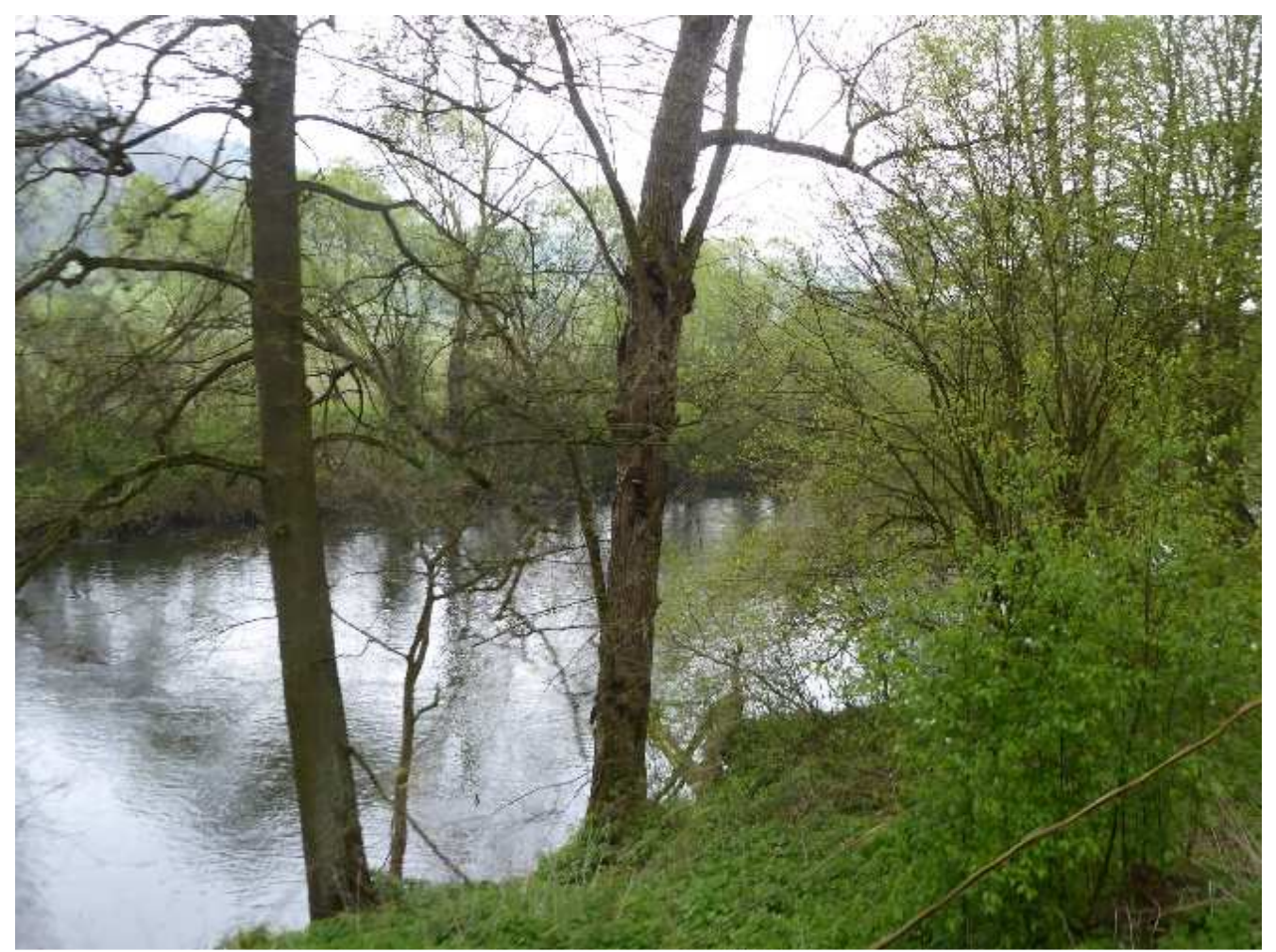

15. The Bóbr River is very close to the track of railway line 283

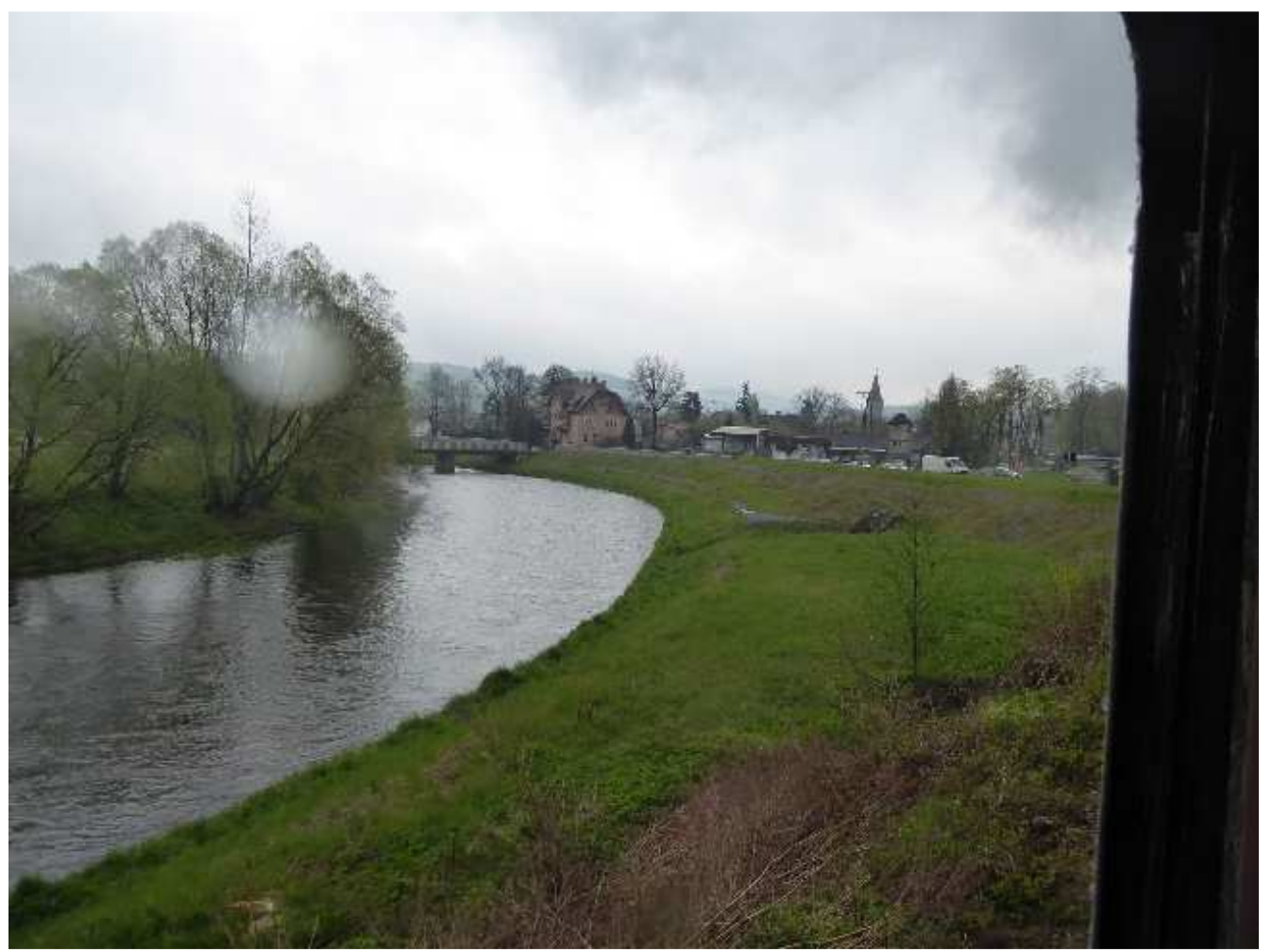

16. Wleń and brook bends during rain 


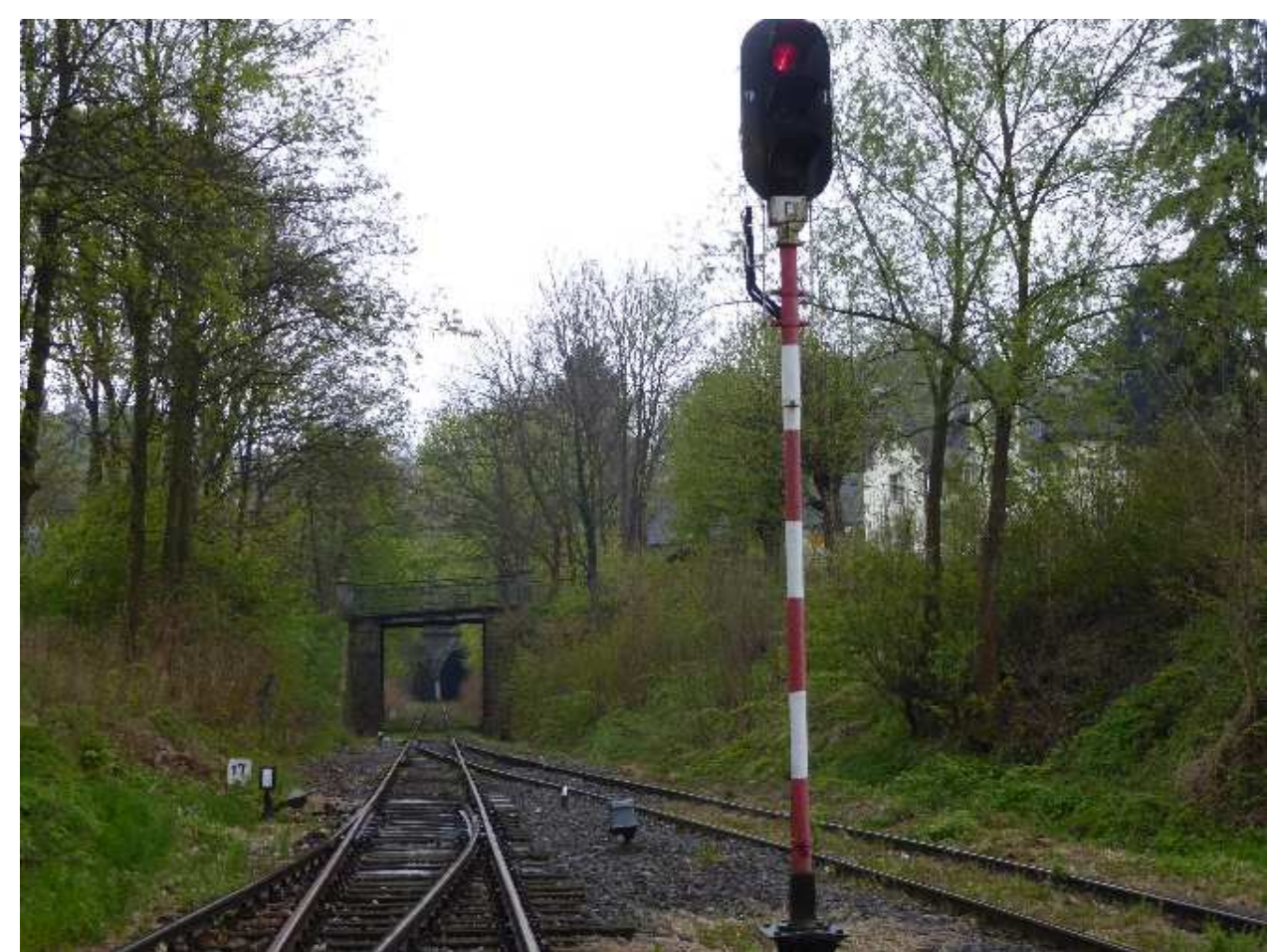

17. Road bridge and tunnel visible from the Wleń station

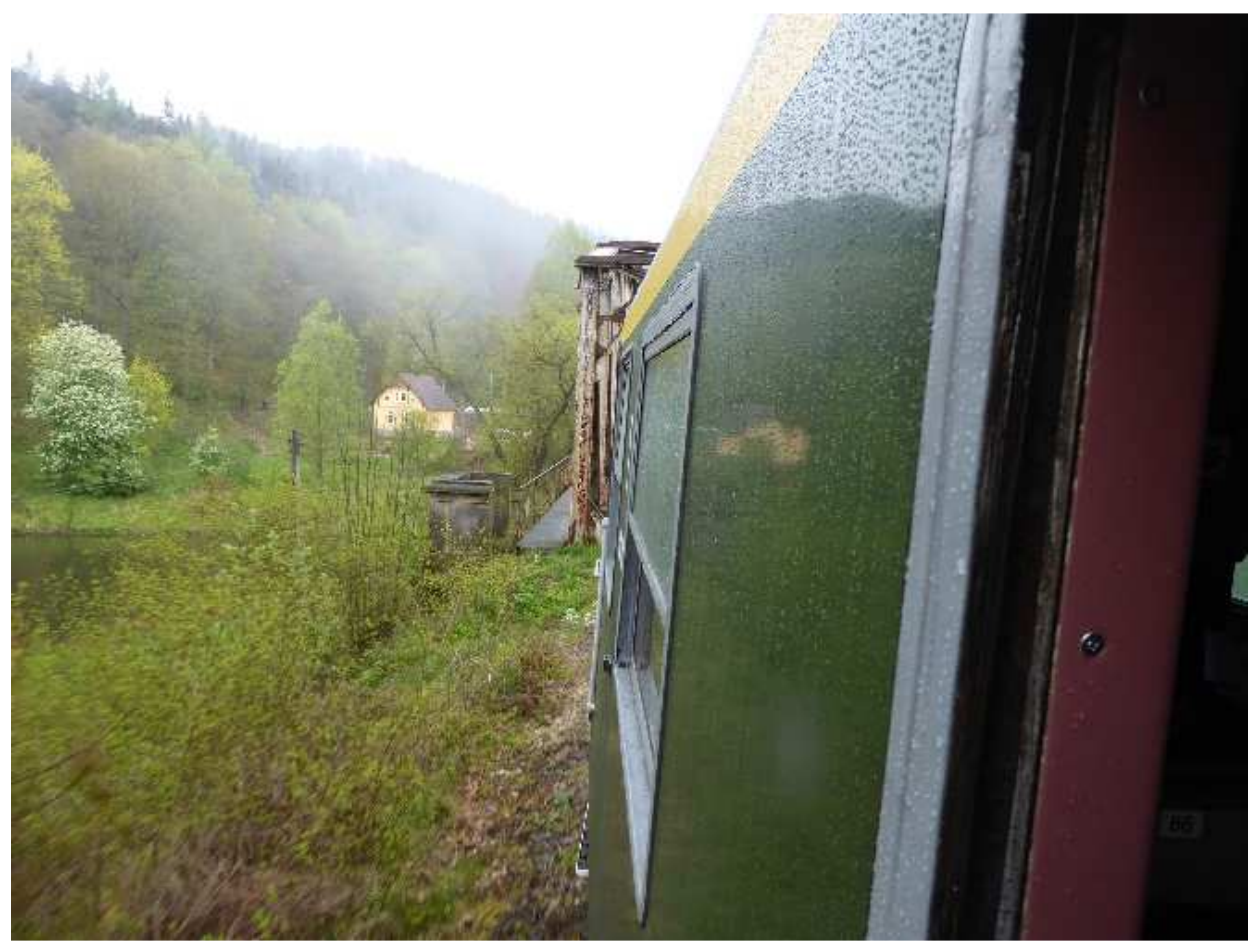

18. The bridge over the Bóbr River between Wleń and Plichowice Nielestno under a rainy sky 


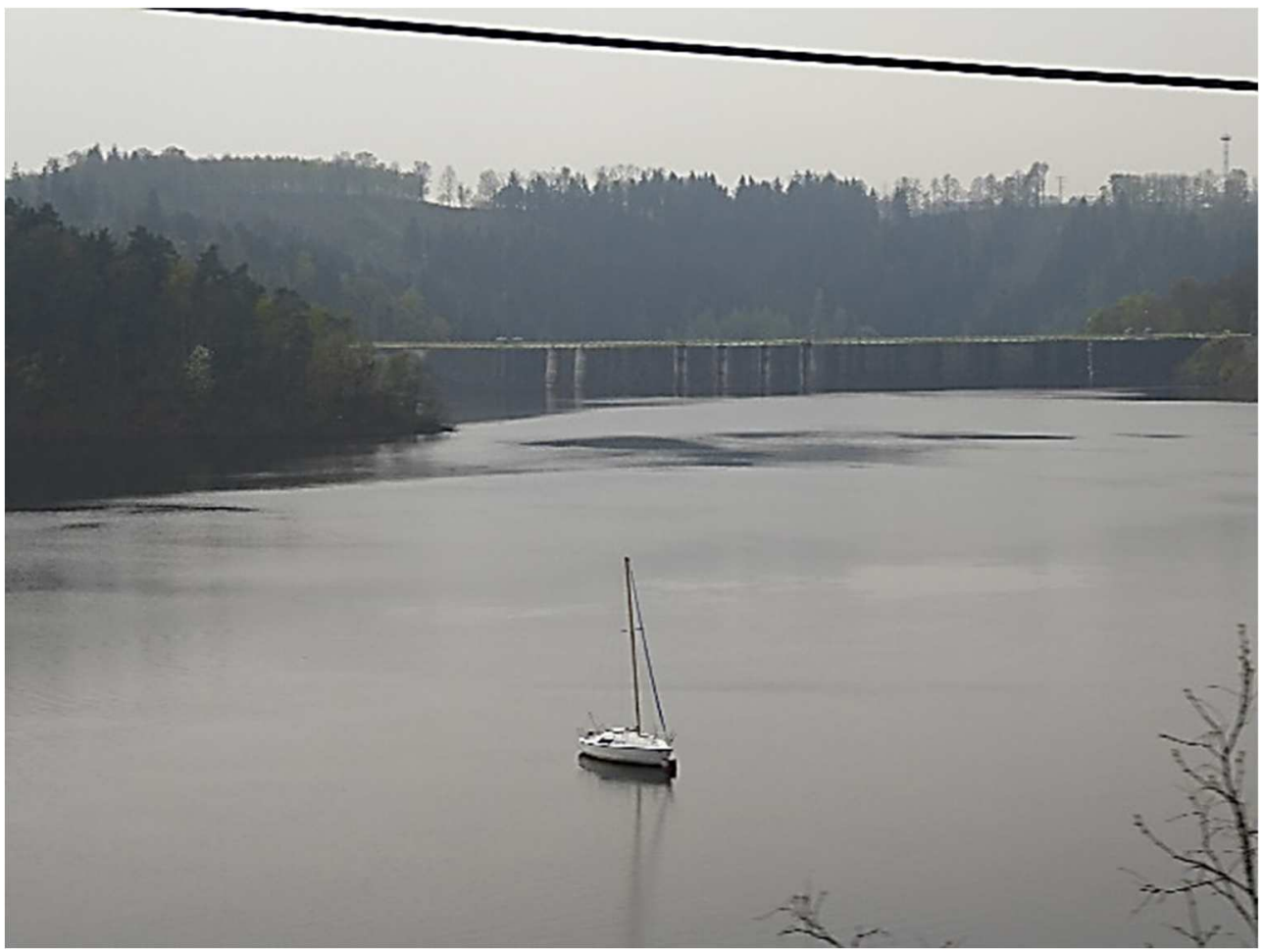

19. Pilchowickie lake and cable

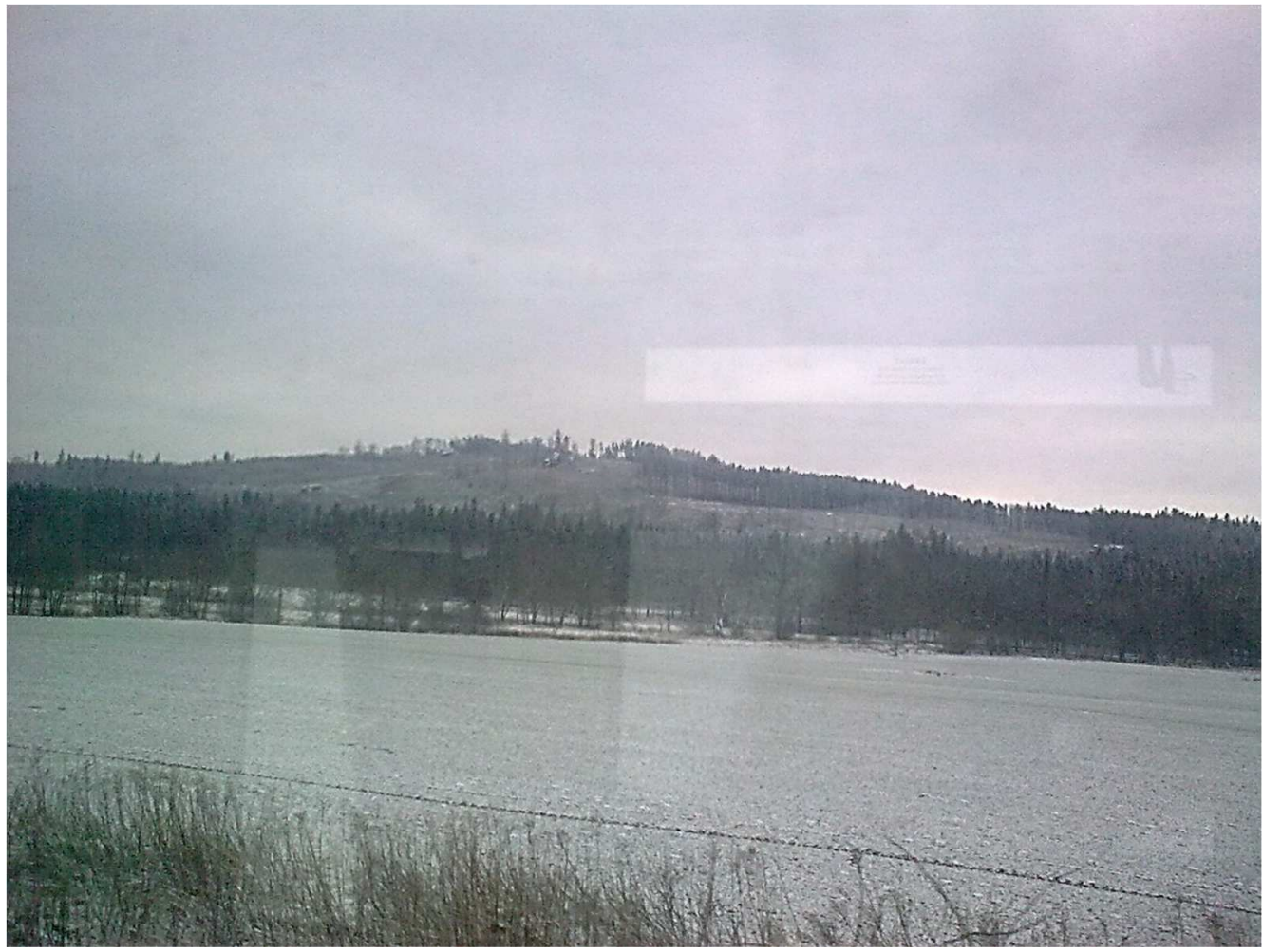

20. Góra Wapienna (507 m above sea level) in the vicinity of Siedlęcin 


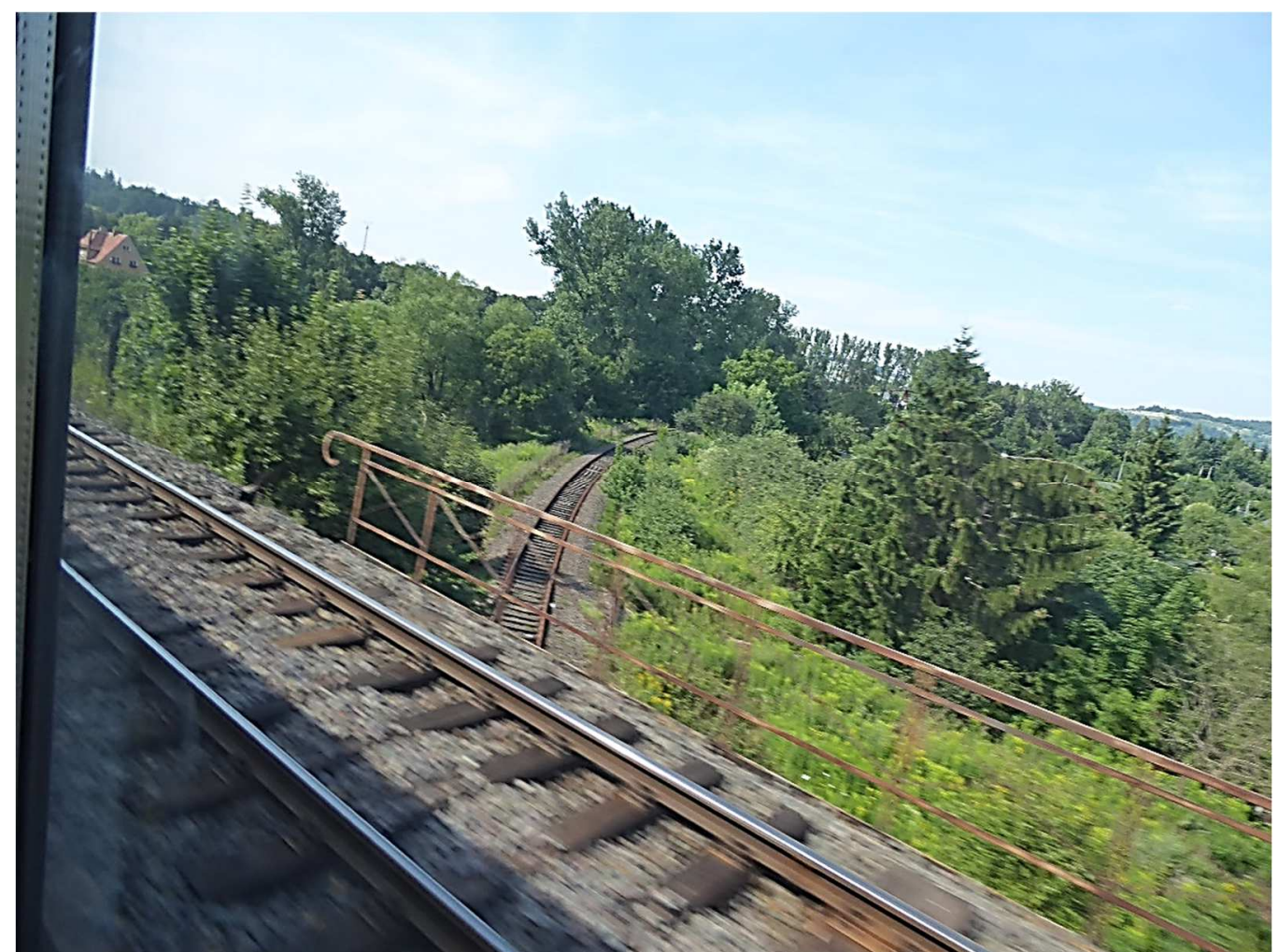

21. View of the 283 line towards Lwówek Slaskie from the viaduct on the 311 Jelenia Góra - Jakuszyce line

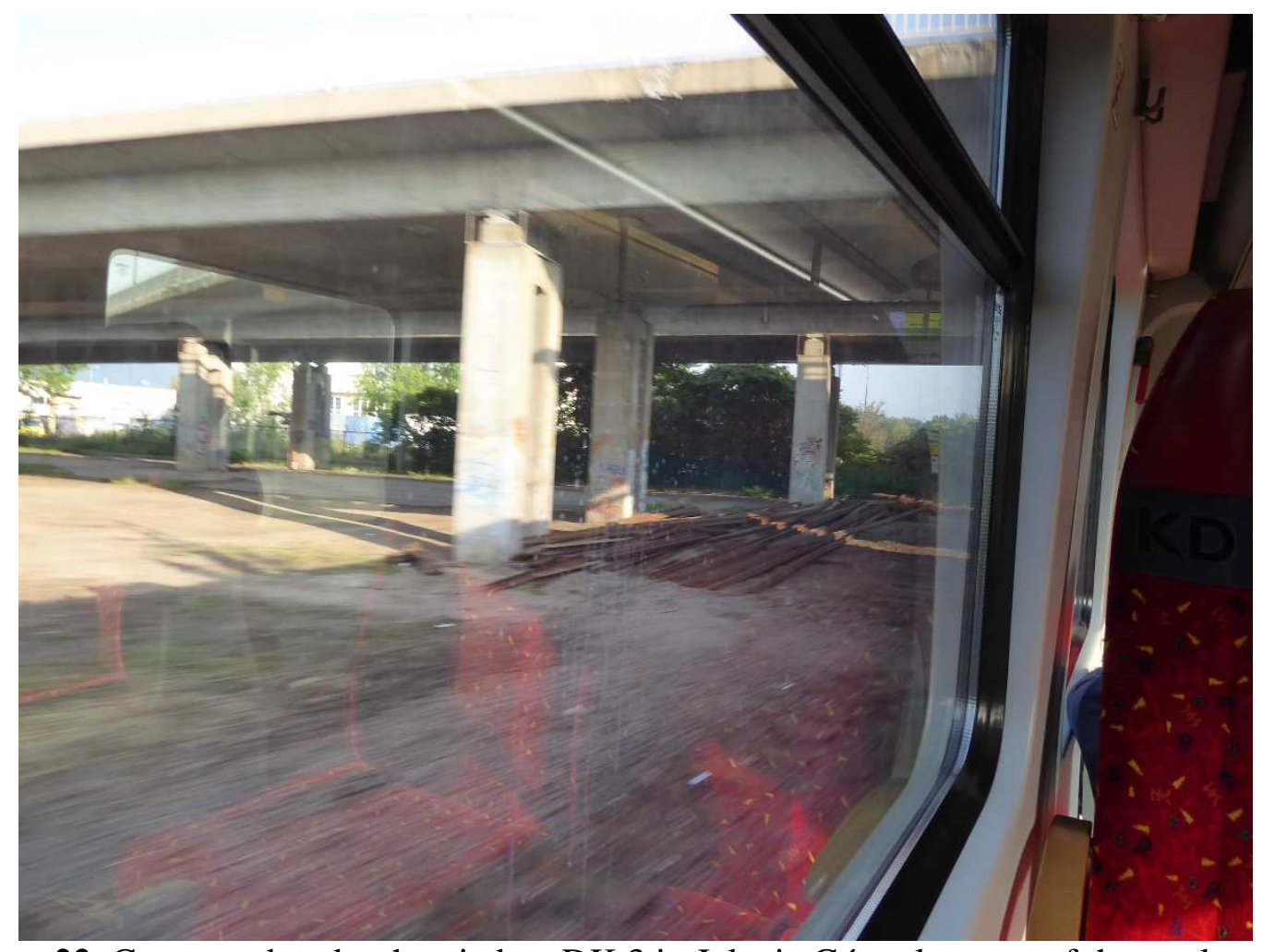

22. Composed under the viaduct DK 3 in Jelenia Góra elements of the track surface line 283 as seen from the train on the 311 line 


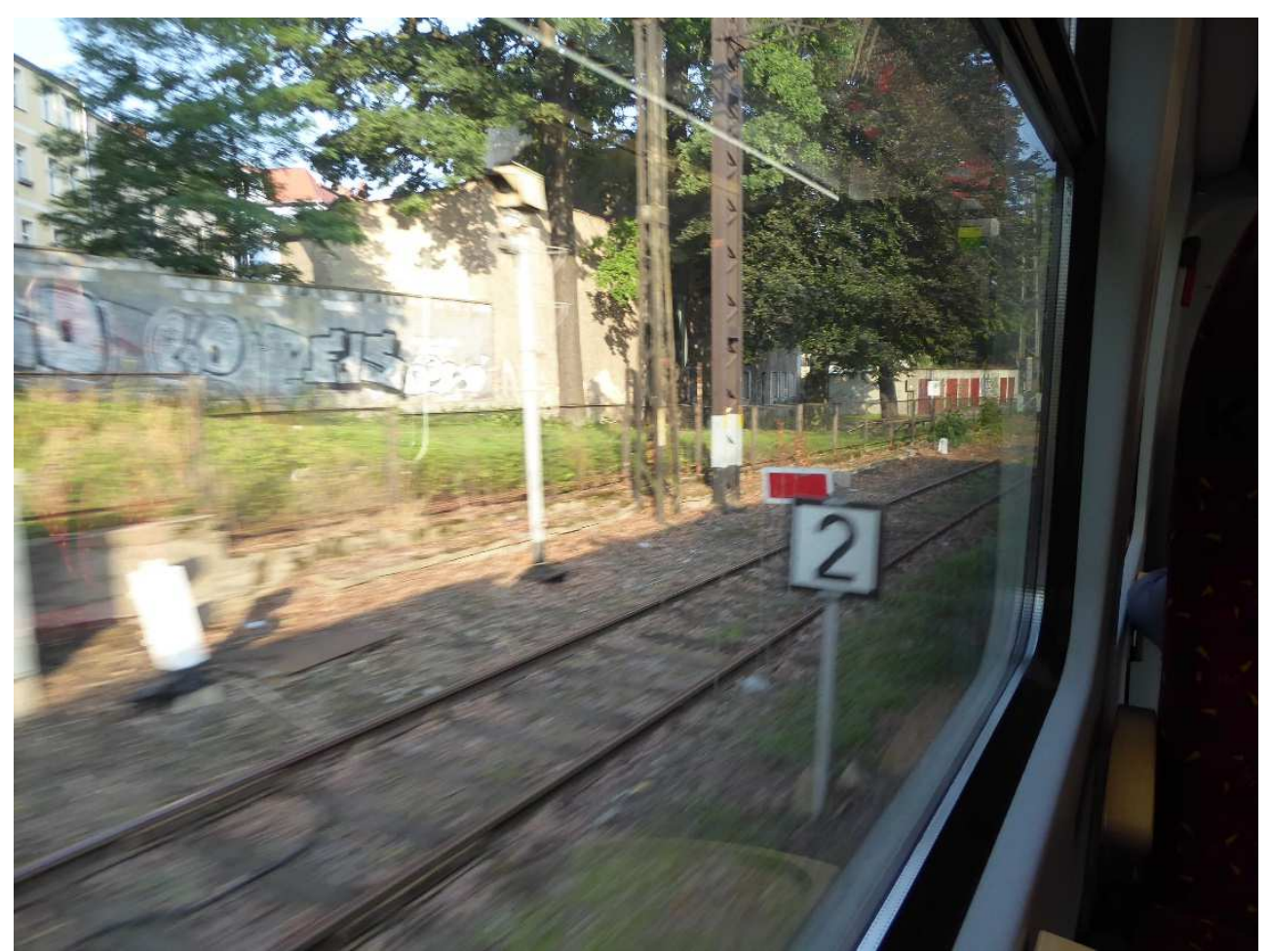

23. Signal D 1 "Stop" given by the stopping disc on the 283 line on the western exit head of the station in Jelenia Góra seen from the train on the 311 line

\section{A proposal to set up the Local Draisine Railway in Dolina Bobru}

Line 283 is in the interest of local governments of Wleń, Lwówek Śląski, and Złotoryja. This line is part of the planned railway connection in the relation Legnica-Złotoryja-Lwówek Śląski-Jelenia Góra. To this end, these local governments organized a series of meetings on securing the line 283 and 284 to restore the railway traffic in this region, where it lives, not counting Legnica and Jelenia Góra, about 68 thousand. people.

On 17 March 2017, a joint session of the Lviv District Council, the Town and Commune of Lwówek Śląski and the Wleń Town and Commune took place, which adopted a resolution regarding the revitalization of the railway line between Jelenia Góra - Wleń Lwówek Śląski - Złotoryja - Legnica.

On April 10, 2017, a conference was held at the Złotoryja City Hall regarding the position regarding the reactivation of the railway line between Jelenia Góra - Wleń - Lwówek Śląski - Złotoryja - Legnica. It was stated that it is necessary to increase the communication accessibility of counties from the region of the Kaczawskie Mountains and Foothills and the Dolina Bobru region. It was assumed that this would contribute to the reduction of unemployment and the activation of people in the labor market who have so far run small farms and undertook seasonal work, and will also increase access to schools and cultural centers for the inhabitants of the region. It was determined that the average speed of travel on this section should be $60 \mathrm{~km} / \mathrm{h}$. In addition, a list of tasks for local governments was adopted, among others: estimation of the number of people commuting daily from the area of individual cities to work and to schools and the volume of mass freight transported abroad $100 \mathrm{~km}$, and to conduct a survey of interest in using the railway line.

On April 12, 2017 during the 3rd National Congress in Wrocław as part of the panel entitled Time for railways Jerzy Michalak from the Board of the Lower Silesian Voivodship UMWD made a declaration on participation with local self-government in the costs of documentation of the functional and utility program for the railway line Legnica - Jelenia 
Góra through Złotoryja, Lwówek Śląski, Wleń [9].On December 4, 2017, with the participation of two deputies to the Sejm of the Republic of Poland and representatives of the Lower Silesian Voivodship and communes of Wlen and Lwówek Śląski, the passage of the Czech Railbus series 810 took place, the so-called railbus (motoraczek) from Jelenia Góra to Lwówek Śląski (Figure 24) [1].

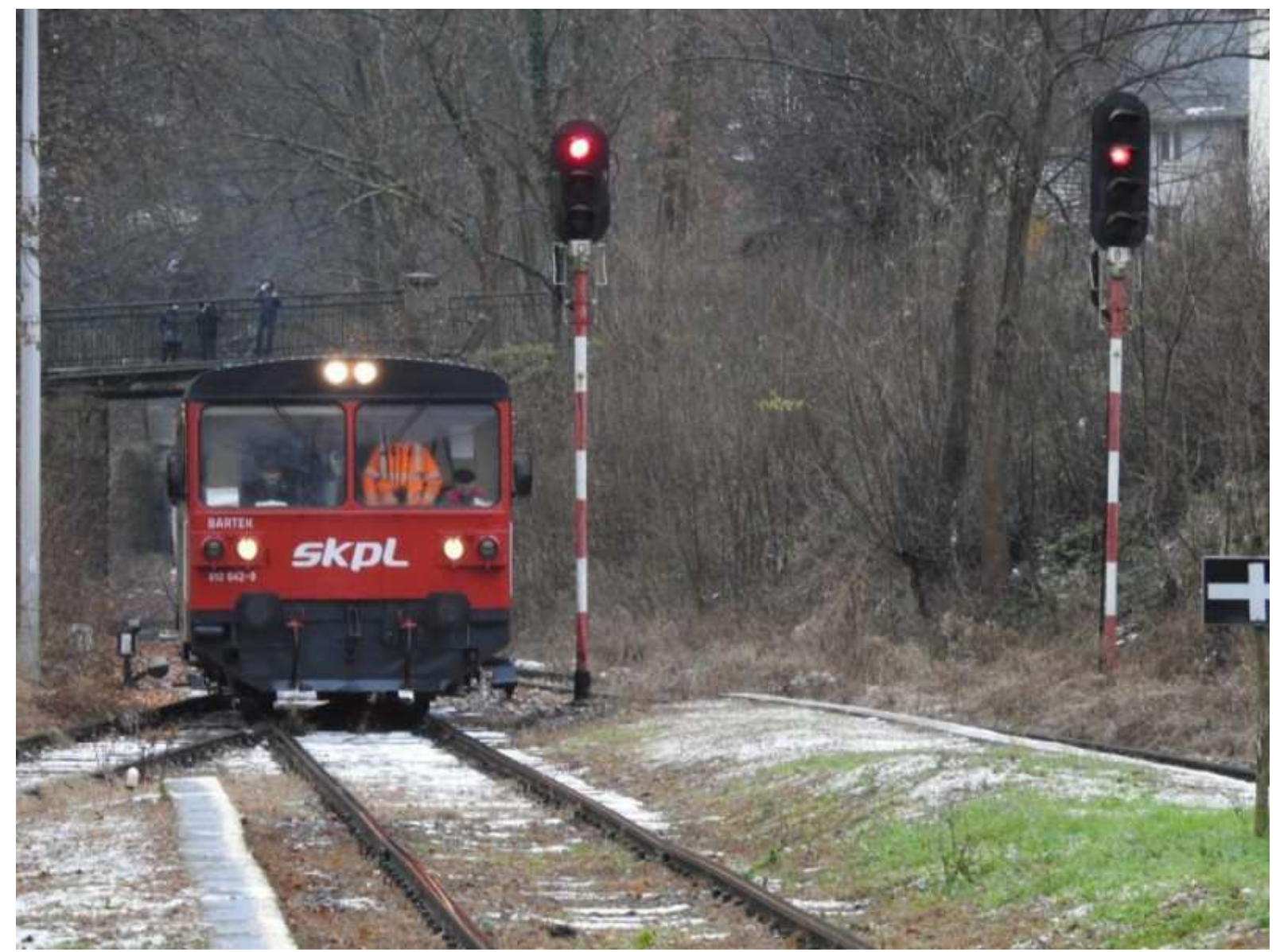

24. Czech railbus (motoraczek) in Wleń (Author Piotr Słowiński, Radio Wrocław, 2017) [22]

Due to the decision of PKP PLK of April 23, 2018, to enter the speed of $0 \mathrm{~km} / \mathrm{h}$ on the section Jelenia Góra - Rakowice Żwirownia these plans are really endangered. Section 283 of the closed line is marked in red in Figure 3. In order to secure the line from devastation, one should find an attractive tourist solution with low investment expenditures. One of them is the use of the lowland line 283 between Wleniu and Lwówkiem Śląski to cross-country bicycle trams. For this purpose, a joint initiative of the Lviv District Council, the City, and Commune of Lwówek Śląski and the City and Commune of Wlen is justified. They would be able to set up the Local Draisine Railway for Dolina Bobrowa. Local governments could report to the Marshal's Office of the Lower Silesian Voivodship with an initiative under the working title: "Protection of the Dolina Bobrowa landscape area by channeling tourist traffic as a result of using the railway line for bike draisines".

As the first step, the Lwówecki Poviat should apply to the UMWD in accordance with the Acts [25] [26] [27] for a free takeover from PKP PLK of this section of line 283 for purposes related to infrastructure investments for the implementation of own tasks of these self-government units in the field of transport .

The next step would be to establish ownership and participate in operating costs. Of course, you should also determine the number of bicycle trolleys and their type. In addition, it is advisable to determine the stationing of bicycle trams, e.g. at the Lwówek Sląski station. 
Then it is necessary to determine the offer. It could be:

- cyclical timetable, every second hour of an odd trip from Lwówek Śląski to Wleń, and in the even return journey,

- custom events, draisine railway or railbus (motoraczek),

- races in uphill rides, e.g. from Wleń to Pilchowice Nielestno with a prize of 2 kegs of beer from breweries from Wleń and Lwówek Śląski interchangeably with a year-long admission ticket to all museums and local museums in the Wleń and Lwówek Śląski communes (e.g. Lenno castle or a free weekend at the Brunów Palace).

Some hope that the railway line 283 on the section Lwówek Śląski - Jelenia Góra will again be passable and used in regular traffic, gives it a shot in the government plan for the reconstruction of local connections announced on October 17, 2018 as point 19. Works on the railway line Legnica - Złotoryja - Jelenia Góra / Świeradów-Zdrój and revitalization of the Lwówek - Zebrzydowo line [20]. The idea of revitalizing the connection between Legnica Złotoryja - Lwówek Śląski - Jelenia Góra was already written in 2013 (vide PK 2013, 2, 2227.) (Note: cars).If rail transport in Legnica - Złotoryja - Lwówek Śląski - Jelenia Góra was started, the rolling stock train could be passed eg to Świeradów Zdrój (draisining under Stog Izerski), Kowar (Uranowa draisine), or under the castles in Bolków and under the castle Grodziec. There, you could organize events related to draisine railways.

\section{Summary}

The journeys of the railway draisines cannot be considered only as a manifestation of railway hobbyists' activities. It can be an element of the strategy of local self-government in the protection of railway lines against their dismantling. Self-government support for hobbyists does not have to relate only to legal facilities, but above all as an aid in the purchase of rolling stock and maintenance. However, these actions may be insufficient if there are people in the local government who do not understand the transport and transport potential of the railway line. A suggestion of the Local Draisine Railway in Dolina Bobru was presented, which may be a form of promoting tourist values and, above all, securing the railway line against liquidation. In case if the current decision of PKP PLK to close the railway line No. 283 socalled The railway of the Dolina Bobru was dictated by the intention of handing it over to the UMWD, it will be a correction of this article.

\section{Source materials}

[1] Admin: Motoraczek we Lwówku Ślaskim. Testowy przejazd na trasie linii kolejowej Doliny Bobru, infolwowek24.pl, Grudzień 4, 2017, https://infolwowek24.pl/motoraczek-we-lwowku-slaskim-testowy-przejazd-trasie-liniikolejowej-doliny-bobru/

[2] Bajda Paulina: Drezyny Rowerowe w Ustrzykach Dolnych, [w] Bieszczadzkie Drezyny Rowerowe ruszyły z Ustrzyk Dolnych, Gazeta Bieszczadzka, sierpień 2015 r., http://www.bieszczadzka24.pl/fotorelacje/bieszczadzkie-drezyny-rowerowe-ruszyly-zustrzyk-dolnych/9

[3] Biuro Podróży PAWUK- Organizator Turystyki w Bieszczadach, Biuro Turystyki Kulturowej PAWUK Anna Buk: Drezyny rowerowe w Bieszczadach, http://wycieczkibieszczady.pl/drezyny-rowerowe-wypozyczalnia/

[4] Decyzja Burmistrza Miasta i Gminy Radków w dniu 31 .05.2006 r. nr GPiOŚ-7624/134/06 w sprawie określenia środowiskowych uwarunkowań zgody na realizację przedsięwzięcia pod nazwą: Eksploatacja złoża melafiru "Tłumaczów - Gardzień l" na działce nr 570/24 we wsi Tłumaczów gmina Radków". 
[5] Express-Miejski.pl : Trwa likwidacja linii kolejowej, gmina Ząbkowice Śląskie:, 201409-23, http://zabkowice.express-miejski.pl/wiadomosc/18394,trwa-likwidacja-liniikolejowej

[6] Fiszer Kasper: Trwa rozbiórka linii kolejowej do Złotego Stoku, Kamieniec Ząbowicki / Złoty Stok, Express-Miejski.pl, 2017-09-08, Ząbkowice Śląskie. http://zabkowice.express-miejski.pl/wiadomosc/29834,trwa-rozbiorka-linii-kolejowejdo-zlotego-stoku

[7] Gersten Rafał: Karkonoskie Drezyny Ręczne, http://www.drezynykarpacz.pl/index.php?menu=1\&go=start

[8] Główczyk Robert: Znika historyczna linia. Regionalny Tygodnik Informacyjny. Kamienna Góra, Czwartek 18.01.2018r. s. 5.

[9] Gmina Miejska Złotoryja: Reaktywacja linii kolejowej Legnica - Jelenia Góra (284/283) przez Złotoryję, Lwówek Śląski, Wleń. Złotoryja, 10 kwietnia 2017 r.

[10] Grodziska Kolej Drezynowa, http://www.drezyny.kolej.one.pl/index.php\#home

[11] Józef Sz. z Jeleniej Góry: D29 - 283 Linia Jelenia Góra - Żagań, [w] Kolej w Jeleniej Górze i okolicy, http://www.jelenia.rail.pl/

[12] Klub Turystyki Kolejowej "TENDRZAK": Drezyny Kolejowe, http://www.drezyny.pl/

[13] Kolejka powiatowa na złom, 23.9.2014, https://doba.pl/index.php?mod=articles\&func $=$ article\&id=1105\&cat_id=18\&site=dza

[14] Krzywińska Kolej Drezynowa, http://www.krzywinskie.drezyny.com/index.php

[15] Lokalna Kolej Drezynowa, http://www.drezynyregulice.pl/

[16] Mrowińska Marta: "I tylko torów trzeba kawałek, żeby marzenia spetnić nieśmiałe” co $z$ mosińska drezyną?, Gazeta Mosińsko-Puszczykowska, 11 Wrz, 2017, https://www.gazeta-mosina.pl/2017/mosinska-kolej-drezynowa-atrakcja-turystyczna-wmosinie/

[17] Ogólnopolska Baza Kolejowa: Linia Jelenia Góra - Żagań (283), Od kwietnia br obowiązuje tu prędkość $0 \mathrm{~km} / \mathrm{h}$, co oznacza że linia jest nieczynna. info: Andrzej Sibilski;

2018-04-23, https://www.bazakolejowa.pl/index.php?dzial=linie\&id=531\&od=1\&do=74\&ed=0\&ok no=historia

[18] paba: Drezyny Najlepszym Produktem Turystycznym 2015, 20 października 2015, http://www.bieszczadzka24.pl/aktualnosci/-drezyny-najlepszym-produktemturystycznym-2015/441

[19] Roger Bailly, Decauville : ce nom qui fit le tour du monde, 77350 Le Mée sur Seine, Amatteis, 1989

[20] Sadowski Sławomir: Program Uzupetniania Lokalnej i Regionalnej Infrastruktury Kolejowej, Ministerstwo Infrastruktury, 22.10.2018, https://www.gov.pl/web/infrastruktura/program-uzupelniania-lokalnej-i-regionalnejinfrastruktury-kolejowej

[21] Sakowska Magdalena: Linia nr 285 (i 286) Wałbrzych-Jedlina: wszystko się zaczyna, https://walbrzych.dlawas.info, 26.10.2018, https://walbrzych.dlawas.info/wiadomosci/linia-nr-285-i-286-walbrzych-jedlinawszystko-sie-zaczyna/cid,18349,a

[22] Słowiński Piotr: Czeskie motoraczki na tory [FOTO], Radio Wrocław, radiowroclaw.pl, 2017-12-04, http://www.radiowroclaw.pl/articles/view/73044/Czeskie-motoraczki-natory-FOTO

[23] Sowiogórskie Bractwo Kolejowe, http://www.drezyny.org/

[24] Stachowiak - Krzyżaniak Maria: Mosińska Drezyna Kolejowa, 2013 r, http://www.naszedrezyny.pl/mkd-galeria.html 
[25] Ustawa z dnia 28 marca 2003 r. o transporcie kolejowym, Dz.U. z 2003 r., Nr 86, poz.789

[26] Ustawa z dnia 8 marca 1990 r. o samorządzie gminnym, Dz.U. z 1990r, Nr.17, poz. 1875

[27] Ustawa z dnia 8 września 2000 r. o komercjalizacji, restrukturyzacji i prywatyzacji przedsiębiorstwa państwowego „Polskie Koleje Państwowe”, Dz. U. z 2000r. Nr 84, poz. 948

[28] WEN: Ttumaczów: Pociagi pasażerskie wróca na tory?. klodzko.naszemiasto.pl, 201009-13, http://klodzko.naszemiasto.pl/artykul/tlumaczow-pociagi-pasazerskie-wroca-natory, 570770 ,art,t,id,tm.html 